\title{
A Global Review of Vessel Collisions With Marine Animals
}

\section{OPEN ACCESS}

Edited by:

Jessica Redfern,

New England Aquarium, United States

Reviewed by:

Simone Panigada,

Tethys Research Institute, Italy

Russell Christopher Leaper,

International Fund for Animal Welfare

United States

${ }^{*}$ Correspondence:

Renée P. Schoeman

renee.p.schoeman@gmail.com; s214234177@mandela.ac.za

Specialty section:

This article was submitted to Marine Conservation and

Sustainability,

a section of the journa

Frontiers in Marine Science

Received: 04 June 2019 Accepted: 14 April 2020

Published: 19 May 2020

Citation:

Schoeman RP, Patterson-Abrolat $C$ and Plön S (2020) A Global Review of Vessel Collisions With Marine Animals.

Front. Mar. Sci. 7:292.

doi: 10.3389/fmars.2020.00292

\author{
Renée P. Schoeman ${ }^{1 *}$, Claire Patterson-Abrolat ${ }^{2}$ and Stephanie Plön ${ }^{3}$ \\ ${ }^{1}$ School of Environmental Sciences, Nelson Mandela University, Port Elizabeth, South Africa, ${ }^{2}$ Endangered Wildlife Trust, \\ Modderfontein, South Africa, ${ }^{3}$ African Earth Observatory Network, Earth Stewardship Science Research Institute, Nelson \\ Mandela University, Port Elizabeth, South Africa
}

Concern about the effects of maritime vessel collisions with marine animals is increasing worldwide. To date, most scientific publications on this topic have focused on the collisions between large vessels and large whales. However, our review found that at least 75 marine species are affected, including smaller whales, dolphins, porpoises, dugongs, manatees, whale sharks, sharks, seals, sea otters, sea turtles, penguins, and fish. Collision incidents with smaller species are scarce, likely as a result of reporting biases. Some of these biases can be addressed through the establishment of species-specific necropsy protocols to ensure reliable identification of collision-related injury, particularly blunt force trauma. In addition, creating a ship strike database for smaller species can assist in identifying the species most frequently involved in collisions, identifying high-risk areas, and determining species-specific relationships between vessel speed and lethal injury. The International Whaling Commission database on collisions with large whales provides a good example of this type of database and its potential uses. Prioritizing the establishment of a species-specific necropsy protocol and a database for smaller species as well as the identification of high-risk areas for species other than large whales, would be a valuable step toward the mitigation of collisions with smaller species.

Keywords: collisions, ship strikes, marine animals, injury, mortality, high-risk areas, mitigation measures, information gaps

\section{INTRODUCTION}

A vessel collision or strike is defined as any impact between any part of a watercraft (most commonly bow or propeller) and a live marine animal (Peel et al., 2018). Collisions often result in physical trauma to- or death of the animal (e.g., Lightsey et al., 2006; Byard et al., 2012; Neilson et al., 2012; Towner et al., 2012; Moore et al., 2013) and may cause serious damage to the vessel, while people on board are at risk of injury and mortality (Neilson et al., 2012; Ritter, 2012).

Concerns about the effects of collisions on marine animals and their populations primarily originate from the extensive and growing utilization of the world's oceans by commercial and recreational vessels. Between 1890 and 2018, the number of globally registered large commercial vessels (>100 gross tonnage) increased from 11108 to just over 94000 (United Nations Conference on Trade Development, 2018; Lloyds Register of Shipping 1992 in Laist et al., 2001). The largest increase in commercial vessels took place between 1950 and 1980, which coincided with an increase in the amount of ship strikes fatal to large whales, mainly baleen whales (Mysticeti: hereafter referred to as whales) (Laist et al., 2001). In 2005, vessel strikes were identified as a priority by the International Whaling Commission Conservation Committee (IWC-CC) who established the Ship Strike Working Group (SSWG: International Whaling Commission, 2005). The main aim of 
the SSWG is to understand and reduce the threat of vessel strikes to cetaceans, especially whales. One essential contribution has been the establishment of an international centralized database (ship strike database) that contains validated information on cetacean (i.e., whales, dolphins, and porpoises) ship strikes worldwide. Although reporting of incidents to the ship strike database can still be improved, the collation of global data provides valuable insight into the scale of the problem, the factors involved in collisions, population specific vessel strike mortality, and the identification of areas where collisions are commonly observed (Jensen and Silber, 2003; Cates et al., 2017; Panigada and Ritter, 2018).

To date, most scientific publications have focused on collisions between vessels and North Atlantic right whales (Eubalaena glacialis: e.g., Kraus et al., 2005; Parks et al., 2012; van der Hoop et al., 2012, 2015; Davies and Brillant, 2019), fin whales (Balaenoptera physalus: e.g., Williams and O'Hara, 2010; David et al., 2011; Redfern et al., 2013, 2019; Sierra et al., 2014; Panigada et al., 2017), blue whales (Balaenoptera musculus: e.g., BermanKowalewski et al., 2010; Ilangakoon, 2012; Redfern et al., 2013, 2019; Priyadarshana et al., 2015), humpback whales (Megaptera novaeangliae: e.g., Wiley et al., 1995; Alzueta et al., 2001; Neilson et al., 2012; Redfern et al., 2013, 2019; Hill et al., 2017), sperm whales (Physeter macrocephalus: e.g., Carrillo and Ritter, 2010; Fais et al., 2016; Di-Méglio et al., 2018; Frantzis et al., 2019), and Florida manatees (Trichechus manatus latirostris: e.g., Laist and Shaw, 2006; Lightsey et al., 2006; Rommel et al., 2007; Edwards et al., 2016). However, there is increasing evidence that more marine species are at risk of collision, especially within coastal areas frequented by smaller vessels. Our review aims to provide an overview of all marine animal species involved in collisions and evaluates whether our knowledge of vessel strikes with whales can assist in understanding and mitigating vessel strikes with smaller species. We conclude with recommendations for priority actions to address essential information gaps. It should be noted that we acknowledge all work conducted on ship strikes by various intergovernmental organizations [e.g., IWC, Agreement on the Conservation of Cetaceans of the Black Sea, Mediterranean Sea and Contiguous Atlantic (ACCOBAMS), Agreement on the Conservation of Small Cetaceans of the Baltic and North Seas (ASCOBANS)] from which annual-, workshop-, and technical-reports have been produced. However, wherever possible, we referred to peerreviewed publications. Consequently, we do not reference reports that discuss published work.

\section{SPECIES OF MARINE ANIMALS COLLIDING WITH VESSELS}

One of the first collision reports dates back to 1877, when a steamship collided with a small unidentified whale (Allen 1916 in Laist et al., 2001). The first identified species was a sperm whale in 1908 (Laist et al., 2001), after which a gradually increasing number of baleen whale species were identified as struck by vessels. Collisions with smaller marine animals were only recognized around 1980, when Hartman (1979) proposed collisions as the most serious threat to Florida manatees in the U.S. Around the same time, the New York State Marine Mammal and Sea Turtle Stranding Program started a sea turtle stranding database, revealing that $10.6 \%$ of all turtles exhibited evidence of propeller wounds (Gerle and DiGiovanni, 1998). To date, necropsy data, eye-witness collision reports, and anecdotal data suggest that at least 75 marine species have been struck by vessels (Table 1), including baleen whales, smaller toothed whales (Odontoceti: e.g., Parsons and Jefferson, 2000; Stone and Yoshinaga, 2000; Kemper et al., 2005; Byard et al., 2012; Lair et al., 2014), manatees and dugongs (Sirenia: e.g., Ackerman et al., 1995; Meager and Limpus, 2012a), carpet sharks (Orectolobiformes: e.g., Graham and Roberts, 2007; Rowat et al., 2007; Speed et al., 2008), mackerel sharks (Lamniformes: e.g., Speedie et al., 2009; Towner et al., 2012), seals and sea otters (Carnivora: e.g., Kreuder et al., 2003; Byard et al., 2012; Wilson et al., 2017), turtles (Testudines: e.g., Gerle and DiGiovanni, 1998; Chaloupka et al., 2008; Meager and Limpus, 2012b), penguins (Sphenisciformes: Cannell et al., 2016), and even fish (Perciformes: e.g., Brown and Murphy, 2010; Clarey, 2014).

Collision reports for smaller marine species are generally scarce likely due, at least in part, to a reporting bias rather than collisions with smaller species being less frequent. We know that collisions between large vessels and whales may not be reported because vessel crew are not aware of the collision (Dolman et al., 2006). Lack of awareness of a collision is even more likely for smaller species. In addition, fatal collisions with most cetaceans, whale sharks (Rhincodon typus), and sea turtles likely go unnoticed because carcasses of these species sink quickly (van Waerebeek et al., 2007; Speed et al., 2008; Williams et al., 2011; Nero et al., 2013). Even if carcasses float, they may be consumed by scavengers or too decomposed to reach shore. Whether strandings of small and large species are reported with the same probability is also unknown. It is possible that the general public may be less concerned about reporting smaller species, such as penguins and sea turtles, than about reporting large whales and dolphins. Finally, there is no global encouragement nor a global database, like the ship strike database for cetaceans established by the IWC, to report collisions with smaller marine species. These factors make it even more challenging to assess the frequency and consequences of collisions with smaller species than it is for large whales.

\section{POSSIBLE CONSEQUENCES OF COLLISIONS}

Collision incidents have led to concerns about animal welfare, animal conservation, safety of people on board the colliding vessel, and economic consequences as a result of vessel damage. In general, three types of consequences are distinguished: direct (i.e., consequences that are the immediate result of collision), long-term (i.e., decrease in animal fitness over time), and population consequences. Direct consequences can further be categorized as injuries to the animal, injuries to vessel crew, and damage to the vessel. 
TABLE 1 | Table of species identified as struck by vessels.

\begin{tabular}{|c|c|c|c|c|}
\hline $\begin{array}{l}\text { Order/common } \\
\text { name }\end{array}$ & Latin name & $\begin{array}{l}\text { Status (International Union } \\
\text { for the Conservation of } \\
\text { Nature, 2019) }\end{array}$ & Frequency & Reliability \\
\hline
\end{tabular}

\section{Perciformes}

Atlantic sturgeon

Sunfish

\section{Sphenisciformes}

Magellanic penguin

Little penguin

Testudines

Loggerhead sea turtle

Acipenser oxyrinchus oxyrinchus

Mola mola

Spheniscus

magellanicus

Eudyptula minor

Caretta caretta

Vulnerable

Near threatened

Least concern

Frequent scattered

Necropsy/external examination

Frequent scattered

Green sea turtle

Chelonia mydas

Endangered

Lepidochelys kempii

Critically endangered

turtle

Olive Ridley sea turtle

Hawksbill sea turtle

Flatback sea turtle

Leatherback sea turtle

Lepidochelys olivacea

Eretmochelys imbricata

Natator depressus

Dermochelys coriacea

Data deficient

vulnerable

\section{Carnivora}

Northern sea otter

Southern sea otter

Harp seal

Harbor seal

\section{Caspian seal}

Gray seal

South African fur seal

Southern fur seal

Steller sea lion

California sea lion

Northern elephant seal
Enhydra lutris kenyoni

Enhydra lutris nereis

Pagophilus

groenlandicus

Phoca vitulina

\section{Pusa caspica}

Halichoerus grypus

Arctocephalus pusillus

Arctocephalus forsteri

Eumetopias jubatus

Zalophus californianus

Endangered

Endangered

Least concern

Least concern

Endangered

Least concern

Least concern

Least concern

Near threatened

Least concern
Mirounga angustirostris Least concern

$\begin{array}{ll}\text { Frequent locally } & \text { External examination } \\ \text { Rare } & \text { Anecdotal (sailors) }\end{array}$

Necropsy

Frequent scattered Necropsy

Rare

Noticeable locally

Rare

Frequent locally
Rare

Noticeable locally

Rare

Noticeable locally

Noticeable scattered

Noticeable locally

Rare

Rare

Rare

Noticeable locally

Noticeable locally

Brown and Murphy, 2010; Balazik et al., 2012

Porcasi and Andrews, 2001; Lulham, 2006; Clarey, 2014

Anecdotal (unknown) Newshub, 2010

Cannell et al., 2016

Gerle and DiGiovanni, 1998;

Orós et al., 2005; Tomás et al., 2008; Casale et al., 2010; Cardona et al., 2012; Meager and Limpus, 2012b; Foley et al., 2019

Necropsy/external examination

Necropsy

Anecdotal (researcher) Segniagbeto et al., 2017

Necropsy

Necropsy

Gerle and DiGiovanni, 1998;

Davenport and Davenport, 2006; Chaloupka et al., 2008; Meager and Limpus, 2012b; Denkinger et al., 2013; Work et al., 2015;

Segniagbeto et al., 2017; Monzón-Argüello et al., 2018; Foley et al., 2019

Cannon, 1998; Gerle and DiGiovanni, 1998; Witzell, 2007; Foley et al., 2019

Meager and Limpus, 2012b; Foley et al., 2019

Meager and Limpus, 2012b Gerle and DiGiovanni, 1998; Deem et al., 2006; Foley et al., 2019

Anecdotal (researcher) Neilson et al., 2012

Necropsy

Kreuder et al., 2003

Necropsy/clinical Swails, 2005

examination

Necropsy/clinical examination

Goldstein et al., 1999; Swails, 2005; Carretta et al., 2012; Barcenas-De la Cruz et al., 2017

Eyewitness (researcher) Wilson et al., 2017

Necropsy/clinical Swails, 2005 examination

Eyewitness

Wickens and Sims, 1994

Necropsy

Byard et al., 2012

Anecdotal (unknown)

Allen and Angliss, 2013

Necropsy

Goldstein et al., 1999; Carretta et al., 2012; Barcenas-De la

Cruz et al., 2017

Clinical examination
Carretta et al., 2012;

Barcenas-De la Cruz et al., 2017 
TABLE 1 | Continued

\begin{tabular}{|c|c|c|c|c|}
\hline $\begin{array}{l}\text { Order/common } \\
\text { name }\end{array}$ & Latin name & $\begin{array}{l}\text { Status (International Union } \\
\text { for the Conservation of } \\
\text { Nature, 2019) }\end{array}$ & Frequency & Reliability \\
\hline
\end{tabular}

\section{Orectolobiformes}

Indian Ocean whale

shark

Rhincodon typus

Endangered

Frequent scattered

Noticeable locally

Frequent locally

American manatee

Trichechus manatus

Vulnerable

\section{Cetacea}

Harbor porpois

Phocoena phocoena

Least concern

Burmeister's porpoise

Finless porpoise

Phocoena spinipinnis

Neophocaena

phocaenoides

Indo-Pacific humpback Sousa chinensis

dolphin

Atlantic bottlenose Tursiops truncatus

dolphin
Near threatened

vulnerable

Vulnerable

Least concern
Noticeable locally Necropsy

Rare

Rare

Rare

Noticeable locally

Necropsy

Indo-Pacific bottlenose Tursiops aduncus

dolphin

Short beaked common Delphinus delphis dolphin

$\begin{array}{ll}\text { Commerson's dolphin } & \begin{array}{l}\text { Cephalorhynchus } \\ \text { commersonii }\end{array} \\ \text { Heaviside's dolphin } & \begin{array}{l}\text { Cephalorhynchus } \\ \text { heavisidii }\end{array} \\ \text { Hector's dolphin } & \begin{array}{l}\text { Cephalorhynchus } \\ \text { hectori }\end{array}\end{array}$

Least concern

Near threatened

Endangered
Rare

Noticeable locally

Necropsy

Anecdotal/picture (unknown)

Anecdotal/picture (researcher)

Necropsy
Anecdotal/pictures (researcher)

Necropsy

Gudger, 1938a,b; Graham and Roberts, 2007; Rowat et al., 2007; Speed et al., 2008; Ramírez-Macías et al., 2012; Department of Parks Wildlife, 2013

Kelly et al., 2004; Speedie and Johnson, 2008; Speedie et al., 2009

Towner et al., 2012

Borsa, 2006; Meager and Limpus, 2012a; Owen et al., 2012; Meager, 2016

Ackerman et al., 1995; Ávila-Canto et al., 2017; Runge et al., 2017

Jepson, 2005; Camphuysen and Siemensma, 2011; Fenton et al., 2017; Deaville et al., 2018

Anecdotal (researcher) van Waerebeek et al., 2007

Parsons and Jefferson, 2000; Jefferson et al., 2002; Morimura and Mori, 2019

Jefferson, 2000; Parsons and Jefferson, 2000

Lockyer and Morris, 1990; Morgan and Patton, 1990; Bloom and Jager, 1994; Fertl, 1994; Wells and Scott, 1997; McFee and Hopkins-Murphy, 2002; van Waerebeek et al., 2007; Currey, 2008; Wells et al., 2008; Bechdel et al., 2009; Dwyer et al., 2014; Félix et al., 2018

Kemper et al., 2005; van Waerebeek and Leaper, 2008; Byard et al., 2012

Jepson, 2005; Kemper et al. 2005; van Waerebeek et al., 2007; Ritter, 2012; Martinez and Stockin, 2013; Common Wealth of Australia, 2017; Deaville et al., 2018

van Waerebeek et al., 2007

Elwen and Leeney, 2010

Stone and Yoshinaga, 2000; van Waerebeek et al., 2007; International Whaling Commission, 2019b 
TABLE 1 | Continued

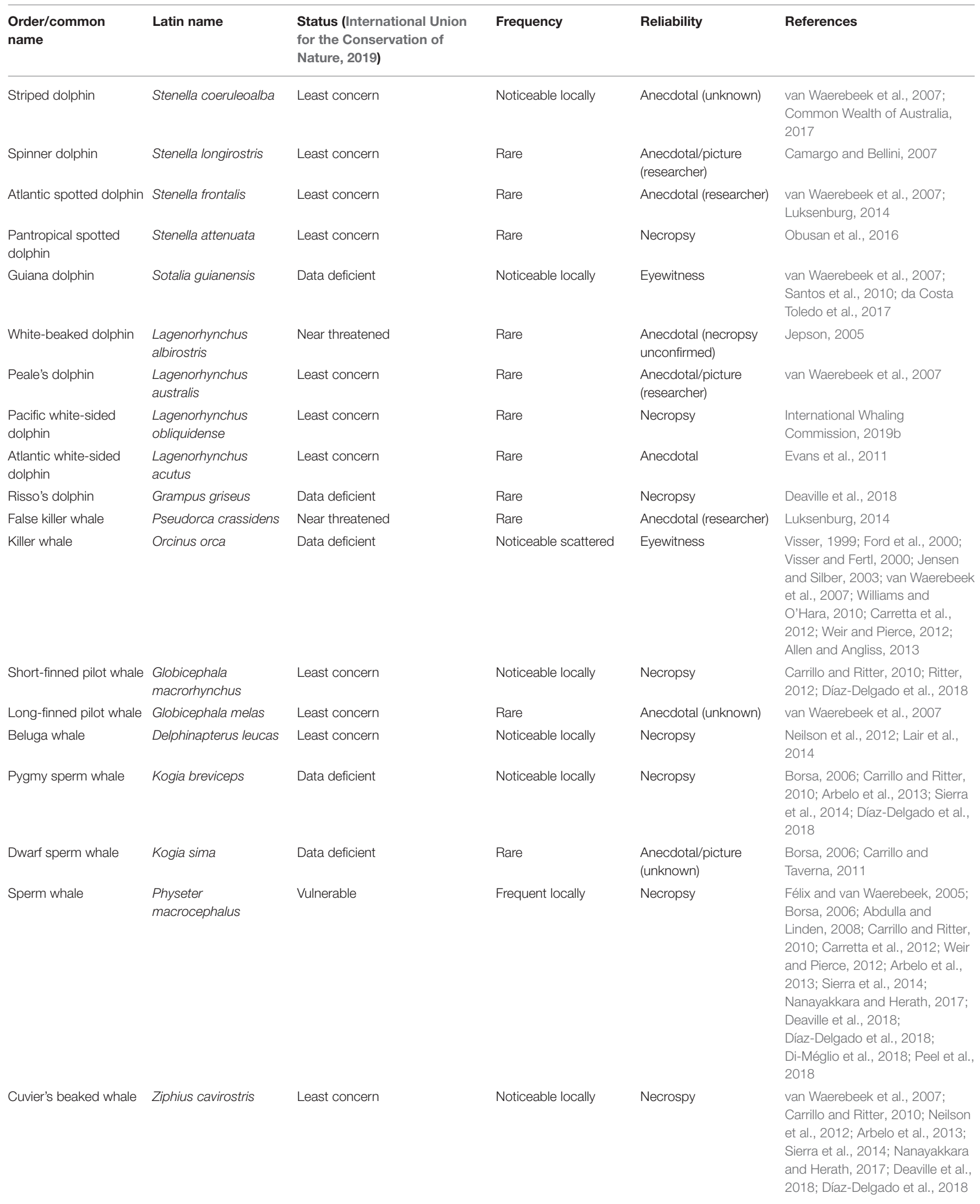


TABLE 1 | Continued

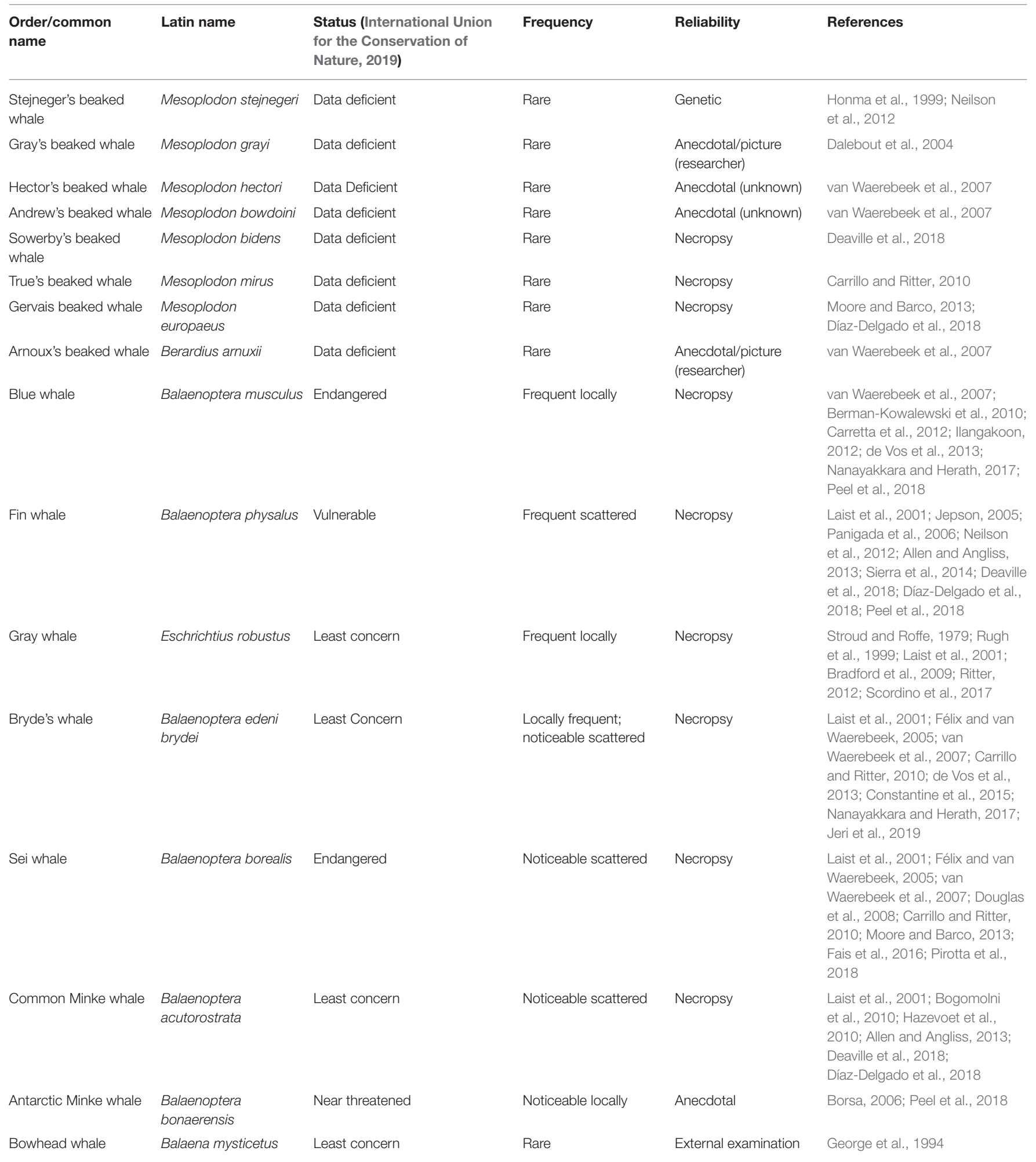




\begin{tabular}{|c|c|c|c|c|c|}
\hline $\begin{array}{l}\text { Order/common } \\
\text { name }\end{array}$ & Latin name & $\begin{array}{l}\text { Status (International Union } \\
\text { for the Conservation of } \\
\text { Nature, 2019) }\end{array}$ & Frequency & Reliability & References \\
\hline Southern right whale & Eubalaena australis & Least concern & Frequent scattered & Necropsy & $\begin{array}{l}\text { Best et al., 2001; Greig et al., } \\
\text { 2001; Rowntree et al., 2001; var } \\
\text { Waerebeek et al., 2007; } \\
\text { McAloose et al., 2016; Cates } \\
\text { et al., 2017; Figueiredo et al., } \\
\text { 2017; Peel et al., } 2018\end{array}$ \\
\hline Northern right whale & Eubalaena glacialis & Endangered & Frequent scattered & Necropsy & $\begin{array}{l}\text { Knowlton and Kraus, 2001; } \\
\text { Moore et al., 2004; Bogomolni } \\
\text { et al., 2010; van der Hoop et al., } \\
\text { 2015; Sharp et al., } 2019\end{array}$ \\
\hline Humpback whale & $\begin{array}{l}\text { Megaptera } \\
\text { novaeangliae }\end{array}$ & Least Concern & Frequent scattered & Necropsy & $\begin{array}{l}\text { Wiley et al., 1995; Neilson et al., } \\
\text { 2012; Díaz-Delgado et al., 2018; } \\
\text { Groch et al., 2018; Peel et al., } \\
\text { 2018; Jeri et al., } 2019\end{array}$ \\
\hline
\end{tabular}

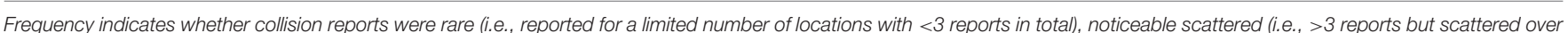

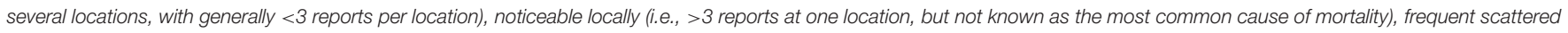

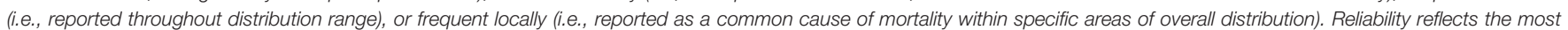

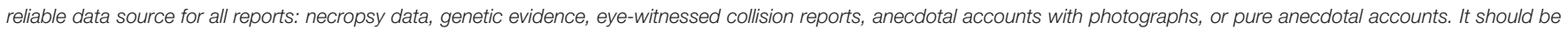
noted that the list of references is not exhaustive, but rather reflects the amount of literature available for each species.

\section{Direct Consequences Injury to the Animal}

Animals incur sharp and blunt force injuries when colliding with a vessel (Figure 1), which can be lethal immediately upon impact as well as several hours, days, or weeks after the incident (Campbell-Malone et al., 2008; Martinez and Stockin, 2013; Dwyer et al., 2014). Both sharp and blunt force injuries have been extensively described for whales and manatees. Sharp force injuries include external gashes and severed tail stocks or fins, mainly originating from contact with a rotating propeller (e.g., Beck et al., 1982; Moore et al., 2004; Lightsey et al., 2006; Rommel et al., 2007; Campbell-Malone et al., 2008; Douglas et al., 2008; Hill et al., 2017). Blunt force injuries predominantly originate from contact with the bow, hull, skeg, or rudder, and are classified as abrasions (i.e., removal of the epithelial layer of the skin), contusions (i.e., hemorrhages), lacerations (i.e., tearing of the skin), and bone or skull fractures (DiMaio and DiMaio, 2001; Lightsey et al., 2006; Moore et al., 2013). Criteria to identify vessel strikes as the cause of death have predominantly been developed from comprehensive necropsies on whales (Moore et al., 2013) and reliable ways to separate ante-mortem from postmortem injuries are becoming increasingly more established (Sierra et al., 2014; Arregui et al., 2019). Furthermore, necropsies and observations of whales and manatees surviving a vessel strike have provided information about the relationship between the severity of injury and depth of laceration (i.e., into the skin, blubber, or muscle), anatomical site of injury, and vessel speed (Rommel et al., 2007; Vanderlaan and Taggart, 2007; Conn and Silber, 2013; Wiley et al., 2016; Combs, 2018). Injured animals experience a reduced welfare because of pain, stress, and possible associated negative psychological states, with the extent of welfare reduction being directly related to the type, severity, and duration of an injury (de Vere et al., 2018).

Our knowledge of vessel strike injuries in whales and manatees has contributed to the identification of vessel-related sharp force injuries in smaller species. The finding that almost every smaller marine species listed within Table 1 has been observed with sharp force injury is likely a result of the relatively easy identification of these injuries. However, there is a lack of knowledge of the species-dependent relationship between the severity of injury and depth as well as location of external gashes. Fatal sharp force injuries on Florida manatees were generally deeper than $17 \mathrm{~cm}$ (Rommel et al., 2007), but a similar wound would be less likely to cause fatal injury to a whale with a thick layer of blubber. In contrast, a similar injury could easily decapitate a fish or penguin. There is also a lack of knowledge of the species-dependent relationship between lethality of injury and vessel speed (see section Vessel-related factors below). Finally, interspecific differences in bone strength may result in different risks of incurring blunt force trauma (Clifton et al., 2008).

\section{Injury to Vessel Crew}

Crew on vessels that collide with whales may get thrown around or thrown into the water, incur injuries, or even die (Neilson et al., 2012; Ritter, 2012; Peel et al., 2018). Reports of these instances are dominated by, but are certainly not exclusive to, small vessels. For example, in March 2019, a Japanese fast ferry was said to have collided with a whale, resulting in serious injuries to at least 13 passengers (Rahim, 2019). In contrast, vessel crew being thrown off their feet because of collision with a smaller marine animal has only been reported anecdotally for fast racing yachts colliding with sunfish (Mola mola) and potentially sharks (Clarey, 2014).

\section{Vessel Damage}

Vessel damage (e.g., cracked hulls, damaged hydrofoils, rudder damage) is commonly reported for collisions between whales and large vessels as well as small vessels (Laist et al., 2001; Neilson et al., 2012; Ritter, 2012). Vessel damage from collisions with smaller marine animals is less frequently reported. However, South African fur seals (Arctocephalus pusillus) occasionally 


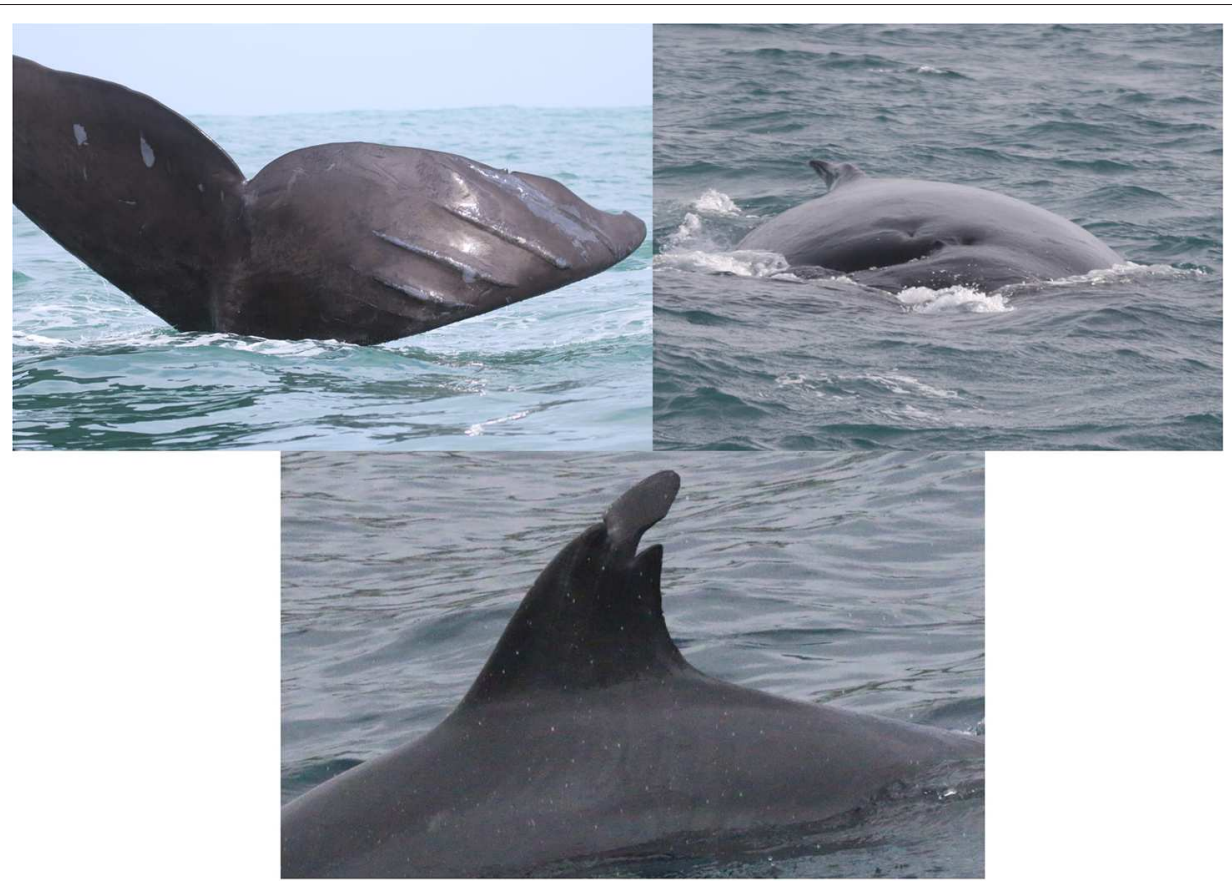

FIGURE 1 | Examples of vessel collision injuries observed on live cetaceans. (Top left) Southern right whale (Eubalaena australis) with a healed propeller injury (Photo credit: Renée Schoeman). (Top right) humpback whale (Megaptera novaeangliae) with suspected blunt force trauma (Photo credit: Titus Shaanika). (Bottom) bottlenose dolphin (Tursiops truncatus) with suspected propeller injury (Photo credit: Michelle Caputo).

come too close to the propellers of fishing trawlers while foraging. These close interactions can result in fur seals incurring propeller cuts and bending or breaking the propeller (Wickens and Sims, 1994). Sunfish are well-known for their damaging effects on sailing yachts and even a large cement carrier incurred paint damage to the hull from colliding with this species (Porcasi and Andrews, 2001; Lulham, 2006). It is surprising that no vessel damage, especially propeller damage, has been reported for collisions between small vessels and sea turtles considering their hard carapace. As mentioned under the section "Species of marine animals colliding with vessels", the limited number of vessel damage reports could be due to reporting biases.

\section{Long-Term Consequences for Individual Animals}

Long-term consequences of collisions for individual animals are not well-understood, but several species indicate longterm locomotive impairments and possible reduced fitness. Locomotive impairments may result from injuries to flukes, flippers, fins, turtle carapace, and even feather disruptions (Jacobson, 1998; Moore et al., 2013; Cannell et al., 2016). These impairments can potentially prevent effective foraging and could ultimately result in death from starvation. An additional concern is that open wounds and bone fractures increase an animal's energy expenditure (Robbins, 1993 in Visser, 1999; Towner et al., 2012). Consequently, more energy is transferred toward body maintenance, while less energy is available for growth and reproduction, which will eventually cause a decrease in individual fitness (Duffus and Dearden, 1993). It is difficult to assess longterm consequences in more detail, but animal tagging as well as photo-ID records of injured individuals could provide more insight into long-term effects of collision injuries on behavior and survival.

\section{Population Consequences}

The impact of collision-related mortality on species and (sub)populations is currently not well-understood (Thomas et al., 2016). A decrease in population growth rate can be caused by a high mortality rate or a decline in fertile animals. The latter is of particular concern for long-lived marine species, which generally have low recruitment rates and an older age of sexual maturity (Heppel et al., 1999). Over time, it is possible that vessel-related mortality might exceed the recruitment rate, either through contributing to a cumulative mortality rate (i.e., mortality from both natural and human-related causes) or on its own (e.g., Kraus et al., 2005; Guo, 2006; van der Hoop et al., 2013; Fais et al., 2016). For species such as North Atlantic right whales (Moore et al., 2004), Hauraki Gulf Bryde's whales (Balaenoptera edeni bryde, New Zealand: Constantine et al., 2015), North Pacific blue whales (Redfern et al., 2013; Rockwood et al., 2017), North Pacific humpback whales (Rockwood et al., 2017), North Pacific fin whales (Rockwood et al., 2017; Keen et al., 2019), and Canary Island sperm whales (Spain: Fais et al., 2016), tools like comprehensive ship strike reporting systems, stranding databases, and modeled risk analyses have helped to identify populations for which ship strike rates may exceed population recruitment rates. 
The impact of mortality rates is starting to be understood for some populations of smaller species, including the Little penguin (Eudyptula minor) population in Perth (Australia: Cannell et al., 2016), the sea turtle populations around Florida (U.S.: Foley et al., 2019), and the Florida manatee (Lightsey et al., 2006). However, for most smaller species, this impact still needs to be assessed.

\section{THE RISK OF COLLISION}

The risk of collision is defined as the probability that a collision occurs, combined with the probability that such a collision will lead to a serious outcome (i.e., major injury, mortality, or damage to the vessel: International Whaling Commission, 2011). Assessing the risk of collision between animals and vessels is an essential step toward the implementation of appropriate mitigation measures in relevant geographical areas (Cates et al., 2017; Crum et al., 2019). Assessments of collision risk require information on animal and vessel distribution patterns and, ideally, on specific vessel- (e.g., size and speed) and animalrelated factors (e.g., time spent at or near the surface and behavioral response to vessels) (Martin et al., 2016; Crum et al., 2019). However, this information is typically not known and targeted research may be needed prior to assessing a species' collision risk.

\section{Identification of High-Risk Areas}

The probability of collision between a vessel and marine animal increases with a higher vessel and/or animal density (e.g., Lagueux et al., 2011; Redfern et al., 2013, 2019; Bezamat et al., 2014; Priyadarshana et al., 2015; Nichol et al., 2017; Rockwood et al., 2017; Di-Méglio et al., 2018). A first important step in collision risk analyses is therefore the identification of highrisk areas: areas where a high number of vessels (shipping lanes, shipping routes, and port approaches) and a relatively high number of animals (areas where a large proportion of the population aggregates or return in high numbers on a regular basis) converge (Cates et al., 2017). At present, 14 high-risk areas are listed by the IWC, based on overlaps in the distribution of large vessels ( $>100$ gross tonnage and typically $>30 \mathrm{~m}$ ) and whales/whale strandings (Cates et al., 2017). Collision reports between large vessels and smaller marine animals are rare (Brown and Murphy, 2010; Balazik et al., 2012; Wilson et al., 2017). Hence, overlap between large vessel and smaller species distribution patterns requires further research.

Overall, there has been a focus on large vessels, because reports have shown that these pose a higher risk to whales (Laist et al., 2001; Jensen and Silber, 2003). While large vessels may indeed increase the risk of lethal injury, there is sufficient evidence that all vessels collide with whales (Best et al., 2001; Neilson et al., 2012; Wiley et al., 2016; Peel et al., 2018) and that even vessels $<15 \mathrm{~m}$ can cause fatal injury when traveling at high speed (Ritter, 2012). In addition, various marine species in Table 1 frequent estuarine and coastal waters, either permanently (e.g., estuarine fishes, penguin species with colonies near or on a mainland, seal species with haul-out sites near or on a mainland, manatees, dugongs) or temporarily (e.g., marine turtles during their nesting season, whale sharks, basking sharks, some dolphin species, and mother-calf pairs of some whale species). Species that occur in coastal waters are specifically at risk of collision with small- and medium-sized vessels that occur in high densities near urbanized coastal regions. Efforts should therefore also be put into the identification of high-risk areas based on small vessel traffic, especially in areas where these dominate collision reports (Neilson et al., 2012).

Information on small vessel distribution patterns is difficult to obtain, compared to data on large vessels that emit regular GPS position data and concentrate in shipping routes, shipping lanes, and port entrances. However, simultaneous studies on animal and vessel distribution patterns as well as local vessel registry data have previously assisted in the identification of areas of concern (Preen, 2000; Maitland et al., 2006; Foley et al., 2019).

\section{Factors Affecting the Risk of Collision}

After high-risk collision areas are identified, a risk-analysis can be performed that ideally constitutes two steps: (1) modeling the probability of a collision based on encounter rate theory and (2) modeling the probability that the collision is fatal (Martin et al., 2016; Crum et al., 2019). Risk analyses based on encounter rate theory, model the probability that an animal and vessel will be close enough in time and space for an encounter (Martin et al., 2016). Whether an encounter (a) results in a collision and (b) is lethal, depends on both vessel-related (e.g., speed, draft, size) and animal-related factors (e.g., dive pattern, vessel avoidance: Martin et al., 2016; Crum et al., 2019). However, most studies have assessed the overlap between vessel and whale distributions to calculate the probability of an encounter (Fonnesbeck et al., 2008; Redfern et al., 2013; Di-Méglio et al., 2018; Pirotta et al., 2018; Frantzis et al., 2019), or have combined overlap in distributions with vessel speed to model probabilities of a lethal collision (Vanderlaan et al., 2008; van der Hoop et al., 2012; Currie et al., 2017; Nichol et al., 2017; Redfern et al., 2019). Below we list the most important factors, discussing potential differences between species.

\section{Vessel-Related Factors}

A broad range of vessel types are involved in collisions (Table 2). A vessel poses a higher risk when traveling at a higher speed, because higher speeds result in a stronger impact (i.e., higher force) and increase the risk of serious blunt force trauma (Wang et al., 2007). However, the relationship between vessel speed and severity of injury is a species-dependent relationship that varies between vessel types. For example, Vanderlaan and Taggart (2007) found that the probability of a lethal injury for whales decreased to $<50 \%$ when large vessels slowed down to 10 knots. Small vessels traveling at a speed of 10 knots are likely to have an even lower probability of lethal injury for whales. In contrast, small vessels (3-6 $\mathrm{m}$ in length) had to slow down to at least 7.5 knots to decrease the probability of lethal injury to loggerhead sea turtles (Caretta caretta: Work et al., 2010), highlighting a clear difference between species. The species-dependent relationship between vessel speed/type and lethal injury is not well-understood and needs further investigation to support the development of mitigation measures that are appropriate for each species. In addition to a higher probability of lethal injury, high 
TABLE 2 | Summary of vessel classes involved in collisions with marine animals, including their typical length in meters (modified after Laist et al., 2001; Lammers et al., 2003; Neilson et al., 2012) and characteristics contributing to collision risk.

\begin{tabular}{|c|c|c|c|}
\hline Vessel class & Length & Examples & Characteristics contributing to collision risk \\
\hline Un-motorized small & $<15 \mathrm{~m}$ & Canoes/kayaks/paddle skies & Silent \\
\hline Un-motorized medium & $15-30 m$ & Medium sailing & Silent, potentially high speed (racing yachts) \\
\hline Motorized small & $<15 \mathrm{~m}$ & $\begin{array}{l}\text { Commercial fishing, police, recreational high-speed, } \\
\text { research, and wildlife watching vessels }\end{array}$ & $\begin{array}{l}\text { Coastal waters, some intentionally come close to } \\
\text { animals, potentially high speed, potentially erratic } \\
\text { movements }\end{array}$ \\
\hline Motorized medium & $15-30 m$ & $\begin{array}{l}\text { Coast guard, commercial fishing, navy, research, } \\
\text { and whale watching vessels, passenger ferries }\end{array}$ & $\begin{array}{l}\text { Coastal waters, some intentionally come close to } \\
\text { animals, potentially high speed }\end{array}$ \\
\hline Motorized large & $30-80 \mathrm{~m}$ & $\begin{array}{l}\text { Coast guard, commercial fishing, navy, and } \\
\text { research vessels, passenger ferries, icebreakers, } \\
\text { whaling boats }\end{array}$ & Mass, potentially high speed, manoeuverability \\
\hline Motorized very large & $>80 \mathrm{~m}$ & $\begin{array}{l}\text { Aircraft carriers, coast guard vessels, container } \\
\text { vessels, cruise ships, dredgers, navy vessels, } \\
\text { passenger/car ferries (normal, jetfoils, catamaran, } \\
\text { trimaran), research vessels, steam ships, tankers }\end{array}$ & Mass, potentially high speed, manoeuverability \\
\hline
\end{tabular}

vessel speeds result in a decreased probability of detection of marine animals by vessel operators and vice versa, resulting in a higher probability of collision (Hazel et al., 2007; Gende et al., 2011). Even if vessel operators are aware of an animals' location, the ability to avoid that animal will depend on the detection distance, vessel speed, and vessel maneuverability (i.e., vessel type). Small vessels may be able to move out of the way, even when an animal is close and the vessel is going at high speed, due to better maneuverability. In contrast, large vessels have less maneuverability (i.e., greater response time to initiate and adjust an avoidance maneuver and a greater turning angle) and would need large distances to avoid an animal (Agreement on the Conservation of Small Cetaceans of the Baltic North Seas, 2011).

Large vessels also have deeper drafts and thus, a larger strike zone (i.e., position of animal beneath the surface at which encounters with a vessel result in a collision). The species-specific extent of the strike zone depth in relation to a vessels' draft is currently not known. Silber et al. (2010), however, conducted limited tests of hydrodynamic effects in collisions using scale models of a container ship and a right whale, with the whale at depths up to two times the draft of the vessel. Over $50 \%$ of trials resulted in propeller strikes if the whale was considered to act as a rigid body. The effect of vessel draft on the risk of collision needs further research as increased strike zone depths increase estimated species mortality rates (Rockwood et al., 2017). Other vessel-related factors that could play a role are the vessels' acoustic signature (i.e., acoustic signal produced by a vessel mainly from onboard machinery and propeller cavitation), which affects the probability that an animal will hear the upcoming vessel (Leal et al., 2015). Hydrodynamic forces may also be important (Silber et al., 2010; Allen et al., 2012). These forces are likely of significance for small and slow moving species, such as sea turtles, near large vessels and fast-moving small vessels (Work et al., 2010).

\section{Animal-Related Factors}

Which animal-related factors (e.g., time spent at surface, type of behavior at surface, behavioral response to vessels, hearing capabilities) affect the risk of collision is not well-understood. One important factor is the amount of time a species spends at or near the surface. Surface time within species may follow a diurnal pattern related to behavior (e.g., Izadi et al., 2018; Keen et al., 2019), but can also vary between individuals of different age classes (e.g., Wiley et al., 1995; Knowlton and Kraus, 2001; Kreuder et al., 2003; Hazel and Gyuris, 2006; Panigada et al., 2006; Carrillo and Ritter, 2010; Neilson et al., 2012; Foley et al., 2019) and sexes (e.g., Kreuder et al., 2003; Panigada et al., 2006). For example, Bryde's whales in the Hauraki Gulf (New Zealand) spent $75-100 \%$ of night-time hours in an inactive state (i.e., resting) with dive depths of $<9 \mathrm{~m}$ (Izadi et al., 2018). Keen et al. (2019) modeled fin whale ship strike risk in the California Current System considering diel patterns of surface use and found that night-time collision risk was twice as high as the daytime risk. The dominant behavior of North Atlantic right whale mother-calf pairs during a calf's first 9 months is comprised of surface resting and nearsurface feeding behavior (45-80\% of time: Cusano et al., 2019). Similarly, lactating female humpback whales in Exmouth Gulf (Australia) spent $53 \%$ of their time within $3 \mathrm{~m}$ of the surface (Bejder et al., 2019). Animals at or near the surface are at risk of collision because they are within reach of a vessels' hull and propeller.

One question that remains difficult to answer is why animals do not move out of the way of approaching vessels. Behaviors such as resting, foraging, nursing, and socializing likely distract animals from risk detection (Dukas, 2002). Furthermore, animals potentially do not hear approaching vessels when near the surface. Sound from a vessel reaches an animal via direct and surface-reflected paths leading to constructive and destructive interference (i.e., Lloyd's mirror effect), with moments when vessel noise may be inaudible to the animal (Gerstein et al., 2005; Thorpe, 2010; Erbe et al., 2016). In addition, acoustic shadows in which radiated ship noise levels approach or fall below ambient noise levels, may form ahead of a vessel (Gerstein et al., 2005), leaving that vessel undetectable to animals in its direct path, especially when at the surface. 
As mentioned under section "Vessel-related factors," vessels have variable acoustic signatures and animals have variable hearing capabilities (Ketten, 2002). Thus, the distance at which certain vessel types can be detected acoustically likely differs between species. However, even if animals can hear/are aware of a vessel, they may not avoid the approaching vessel or they may take avoidance measures that have limited or adverse effects (Stone and Yoshinaga, 2000; Nowacek et al., 2004). A study of tagged blue whales near shipping lanes off the coast of southern California found that whales do not avoid areas of heavy ship traffic (McKenna et al., 2015). McKenna et al. (2015) also found that blue whales at the surface were limited in their ability to avoid collisions with fast ships because individuals responded to approaching ships with a slow descent and no lateral movement away from the ship. There is no single factor that can tell us why some individuals or species are more prone to vessel collisions than others and more species-specific research is needed to understand interspecific differences.

\section{CURRENT MITIGATION MEASURES, THEIR EFFECTIVENESS, AND SUITABILITY FOR SMALLER SPECIES}

A wide variety of mitigation measures that aim to reduce the risk of collisions between vessels and marine animals exist today (e.g., Silber et al., 2012b; Couvat and Gambaiani, 2013; McWhinnie et al., 2018), most of which were developed with a focus on whales. The most suitable mitigation measure(s) depends on the geographic area, environmental conditions, vessels involved, species targeted, time-pressure to implement a mitigation measure, and cost of mitigation (e.g., Weinrich et al., 2010; Silber et al., 2012a; Constantine et al., 2015; McWhinnie et al., 2018). Below we list the mitigation measures that have been developed today and discuss whether they have been effective in the protection of whales as well as whether they could be applied to smaller marine species.

\section{Geographical Measures \\ Re-routing Measures}

Once areas of greatest collision risk have been identified, vessel traffic can be re-routed provided that alternative routes do not compromise safe navigation (e.g., Vanderlaan et al., 2008; Redfern et al., 2013, 2019; Frantzis et al., 2019). Proposals from coastal states to establish or amend routing measures outside, or partially outside, territorial waters need to be submitted to and endorsed by the International Maritime Organization (International Maritime Organization, 1986). In 2009, the IMO published a guidance document to inform member governments about principles to consider when developing actions to reduce collision risk and which guidance documents should be consulted when preparing routing proposals (International Maritime Organization, 2009). Where routing measures fall within territorial waters, decisions can be made directly by coastal states, although these measures may also be submitted to the IMO for revision and approval. Routing measures can be permanent or seasonal, mandatory or recommended, and may apply to all vessels or a sub-set of certain vessel type(s).

Permanent mandatory rerouting measures to prevent ship strikes with whales include Traffic Separation Schemes (TSSs). In June 2003, the TSS in the Bay of Fundy (Canada) was rerouted around the Grand Manan Basin to reduce the risk of lethal encounters between vessels $\geq 300$ gross registered tonnage and North Atlantic right whales (International Maritime Organization, 2003; Vanderlaan et al., 2008). Since then, a TTS has been established or amended near Boston (MA, U.S.: International Maritime Organization, 2006, 2007a), within the Santa Barbara Channel (CA, U.S.: International Maritime Organization, 2012), off San Francisco (CA, U.S.: International Maritime Organization, 2012), and in the approach to Panama City (Panama: Guzman et al., 2012; International Maritime Organization, 2014) to protect North Atlantic right, blue, and humpback whales. Year-round recommended routes have been implemented to and from the Port of Auckland to reduce collision risks with Bryde's whales (Ports of Auckland, 2015; Maritime New Zealand, 2019). Seasonal re-routing measures have also been used to protect whales. Specifically, seasonal, voluntary two-way routes were established in Cape Cod Bay and in coastal waters of the southeast U.S. (SEUS) to protect the North Atlantic right whales (Fonnesbeck et al., 2008; Lagueux et al., 2011).

Vessel traffic exclusion zones aim to reduce the number of vessels in an area. Examples are the permanent, voluntary Area To Be Avoided (ATBA) that was adopted by the IMO in 2017 to protect humpback whales near Costa Rica (International Maritime Organization, 2017) and the seasonal ATBAs in the Great South Channel (off Cape Cod Bay, MA, U.S.) and Roseway Basin (south of Nova Scotia, Canada) to protect North Atlantic right whales (International Maritime Organization, 2007b, 2008; Vanderlaan et al., 2008; Vanderlaan and Taggart, 2009). A less common rerouting measure is the establishment of Dynamic Management Areas (DMAs) in the U.S. DMAs are temporary (i.e., 15 days) management areas, established by the U.S. National Marine Fisheries Service (NMFS) for the protection of North Atlantic right whales from collisions with large vessels (Federal Register, 2008). When a (group of) right whale(s) is sighted, a circle providing an area of $44.5 \mathrm{~km}^{2}$ per whale (i.e., radius of circle is adjusted for the number of right whales in the group), is drawn around the group. Any circle or group of contiguous circles with more than three right whales qualifies to be demarcated as a DMA with a minimum radius of $27.8 \mathrm{~km}$ (Federal Register, 2008). All vessels are asked to voluntarily avoid a DMA (or to reduce their speed to $\leq 10$ knots while transiting the area, see section Speed restrictions) (Federal Register, 2008; Laist et al., 2014).

Rerouting vessel traffic around areas with known concentrations of whales is an effective mitigation measure (International Whaling Commission, 2014; International Maritime Organization, 2016). The risk of collision can be reduced by $60-95 \%$ when compliance with a routing measure is high (e.g., Vanderlaan et al., 2008; Vanderlaan and Taggart, 2009; Guzman et al., 2012; van der Hoop et al., 2012); which generally seems to be the case for IMO adopted routing measures (Silber et al., 2012b). However, compliance with voluntary routing 
measures implemented by coastal states varies. Lagueux et al. (2011) found that compliance of tankers and cargo vessels with recommended routes in the SEUS, increased from 51.7 to $96.2 \%$ over the first 3 years of implementation. In contrast, compliance with DMAs off the U.S. coast as well as a voluntary 'No Go Area' (NGA) in the St. Lawrence Estuary (Quebec, Canada) was low (Silber et al., 2012a; Chion et al., 2018). It should be emphasized that rerouting is not always feasible (i.e., safety of navigation) and that some rerouting measures only apply to large commercial vessels (most TSSs and ATBAs). Therefore, they do not decrease the risk of collision with small vessels. Even if rerouting measures apply to small vessels, it is more difficult to assess compliance because their location and speed are challenging to monitor. Increased compliance may require enforcement, which is difficult to achieve when the geographic area is relatively large (i.e., large area or multiple smaller exclusion zones spread across a large geographic area), or when a country or state does not have the capacity to apply enforcement actions. In addition, several studies have indicated that rerouting measures assisting one species could increase the risk of collision for other species, highlighting the need for a multi-species research approach when assessing the efficacy of rerouting measures (e.g., Redfern et al., 2013; Priyadarshana et al., 2015; Ritter et al., 2019).

Reducing the overlap between vessel traffic and aggregations of animals can also be a successful mitigation method for smaller species. Rerouting TSSs is not possible for coastal species, where most overlap will be found around port entrances. However, vessel traffic exclusion zones can provide opportunities for risk reduction. A small number of no-go-zones was established to protect the Florida manatee (Florida Fish Wildlife Conservation Committee, 2018). This type of measure can potentially be implemented for a much wider variety of animals that aggregate year-round or seasonally in particular areas. Vessel traffic could, for example, be excluded year-round from important dugong habitat in Queensland (Australia), or seasonally (March-July) around loggerhead and green turtle (Chelonia mydas) nesting beaches along the U.S. Florida coast (Maitland et al., 2006; Foley et al., 2019).

\section{Source-Based Mitigation Measures Speed Restrictions}

Implementations of vessel speed restrictions have been suggested to provide animals and vessel crew with more time to detect and avoid each other as well as to reduce the severity of injury (Hazel et al., 2007; Vanderlaan and Taggart, 2007; Gende et al., 2011; Conn and Silber, 2013). The implementation of reduced vessel speeds was first proposed by Laist et al. (2001). Vanderlaan and Taggart (2007) modeled the relationship between vessel speed and probability of lethal injury from collision reports with large whales. They found that the probability of lethal injury decreased to $<50 \%$ when vessels traveled at speeds $\leq 10$ knots. Conn and Silber (2013) used a slightly larger database and found similar results. They also found that the ship strike rate went down as vessel speed decreased. Implementation of vessel speed restrictions to protect whales from collisions with large vessels have been numerous, with vessel speed restrictions ranging from $\leq 13$ to $\leq 10$ knots (e.g., Federal Register, 2008; McKenna et al.,
2012; Ports of Auckland, 2015; Currie et al., 2017; Ritter et al., 2019). Similar to rerouting measures, proposals from coastal states to implement vessel speed restrictions outside territorial waters need to be submitted to and endorsed by the IMO (Silber et al., 2012b). Vessel speed reductions can also be voluntary or mandatory as well as permanent or seasonal.

A reduction in vessel speed has been successful in reducing collision risk and is the preferred measure to implement when vessels cannot be re-routed (International Whaling Commission, 2014; International Maritime Organization, 2016). Humpback whale surveys conducted with a small vessel traveling at speeds between 5-20 knots revealed that whales were three times more likely to be sighted beyond the close encounter distance of $300 \mathrm{~m}$ when vessels traveled at speeds $\leq 12.5$ knots (Currie et al., 2017). In addition, the mean detection distance of close encounters (i.e., $\leq 300 \mathrm{~m}$ ) increased from $190 \mathrm{~m}$ to $211 \mathrm{~m}$ (Currie et al., 2017). A reduction in vessel speed is the only mitigation measure that has been recommended for a variety of smaller marine species, such as manatees (Calleson and Frohlich, 2007), dugongs (Hodgson, 2004), sea turtles (Hazel et al., 2007; Work et al., 2010), and fish (Brown and Murphy, 2010). However, compliance with vessel speed restrictions can be low (e.g., Gorzelany, 2004; Jett and Thapa, 2010; Lagueux et al., 2011; McKenna et al., 2012; Freedman et al., 2017). Vessels traversing DMAs, for example, generally did not reduce their speed to the recommended 10 knots (Silber et al., 2012a). Initial compliance with a mandatory 10 knots speed restriction in Seasonal Management Areas (SMAs) was also low, but improved with targeted enforcement programs (Silber et al., 2014). Similar boater compliance issues were found in speed restriction zones to protect manatees; compliance varied between Sarasota and Lee County sites as well as between vessel types, with a lower compliance by smaller vessels (Gorzelany, 2004; Jett and Thapa, 2010). However, compliance increased in the presence of law enforcement, highlighting that enforcement efforts are important to assure effectiveness of speed reduction measures (Gorzelany, 2004; Jett and Thapa, 2010).

As noted under section "Vessel-related factors," there is no known relationship between vessel speed and collision risk for smaller marine species, mainly because the data needed to infer such relationships have not been collected. Research on sea turtles has indicated that individual turtles are more likely to flee from an approaching vessel when speeds are reduced to 2 knots, while the probability of lethal injury decreased by $60 \%$ for vessels idling at 4 knots (Hazel et al., 2007; Work et al., 2010). Large differences in the relationship between vessel speed and collision risk can therefore be expected between species and more species-specific research is needed to identify these relationships.

\section{Animal Detection Onboard the Vessel}

Collisions with animals can be avoided if animals are detected and appropriate avoidance measures are adopted by the vessel operator. Vessel crew are generally not trained to detect and identify marine animals and are likely focussed on other aspects of the voyage. Placing a trained, dedicated observer onboard a vessel has been suggested to help increase the detection rate of whales along a vessel's route during day-light hours. 
The effectiveness of placing trained, dedicated observers on a ship's deck or bridge to detect whales has been tested for highspeed ferries and commercial cargo vessels (Mayol et al., 2008; Weinrich et al., 2010; Flynn and Calambokidis, 2019). Observers were found to detect more whales than standard vessel crew and often at larger distances from the vessel. This early detection provides vessel crew more time to take avoidance measures. However, as highlighted under section Vessel-related factors, large vessels have less maneuverability and may not be able to effectively avoid whales despite observers effectively locating animals. In contrast, small vessels have greater maneuverability, but observers are closer to the sea-surface reducing the effective sighting distance. Onboard observers are therefore only suitable for vessels that are large enough to provide observers with an elevated platform that enables detecting animals over a sufficient range, but small enough to effectively maneuver. Even in the presence of trained observers, collisions with whales occur when they are not seen or seen too late to take avoidance measures (Wiley et al., 2016). This risk is higher for species that spend more time near the surface instead of at the surface.

During night hours, observers could make use of infrared cameras that create images from infrared radiation emitted by a whale, which is a function of both body and/or blow temperature and spectral emissivity (Cuyler et al., 1992; Horton et al., 2017). The effectiveness of infrared imagery has been addressed in various studies (e.g., Barber et al., 1991; Burn et al., 2009; Graber, 2011; Yonehara et al., 2012), but more data is needed to assess its use for effective mitigation against collisions with vessels (Horton et al., 2017). Woods Hole Oceanographic Institution is currently experimenting with new automatic infrared detection techniques (Lubofsky, 2019). Another aroundthe-clock detection method for marine animals is active sonar: a method to detect objects of various sizes by releasing acoustic energy into the marine environment and subsequently receiving the echoes that bounce off the object (Kozak, 2012). However, the release of acoustic energy is of concern as increased levels of noise are known to negatively affect all species (Popper and Hawkins, 2012, 2016).

Animal detection measures are unlikely to result in a significant decreased risk of collision for smaller species because they are less easily sighted by observers at the distances needed to implement an avoidance measure. In addition, infrared cameras will not work on small-bodied animals, especially without the extra cue of a large blow. The detection range of active sonars decreases with decreasing water depth. Thus, active sonar is unsuitable for shallow coastal areas frequented by species, such as manatees, dugongs, and turtles (Gerstein, 2002).

\section{Deterrent Devices}

Deterrent devices can be installed directly on vessels to alert a marine animal to- and deter them from an approaching vessel without vessel crew needing to detect the animal.

Nowacek et al. (2004) tested the effect of an acoustic alerting stimulus on North Atlantic right whale behavior and found that individuals moved to the surface. This behavioral response would increase, rather than decrease, their collision risk. Lagerquist et al. (2013) did not observe any avoidance of an acoustic deterrent device by Gray whales (Eschrichtius robustus) migrating along the Oregon coast. Hence, there is currently no evidence that acoustic deterrent devices work for whales. Gerstein and Blue (2004) developed a Manatee Alert Device (MAD) that sends out a low intensity, highly directional sound. Ninetyfive percent of manatees elicited an avoidance response during test trials (Gerstein and Gerstein, 2017). In addition, manatees avoided the active MAD at a greater mean distance $(20 \mathrm{~m})$ in comparison to non-active controls (6 m: Gerstein and Gerstein, 2017). Lenhardt (2002) developed an alerting device for sea turtles that emits acoustic signals from 0.2 to $15 \mathrm{kHz}$ as well as a visual deterrent cue to a) initiate a fleeing response and b) direct animals away from the vessel because turtles flee in the direction that they are facing. However, there are no data available on the effectiveness of this turtle alerting device. There are also concerns that sounds emitted by acoustic deterrent methods potentially cause acoustic trauma (i.e., hearing loss), displace animals from important habitats, or affect nontargeted acoustically sensitive marine species (Johnston and Woodley, 1998; Morton and Symonds, 2002; Olesiuk et al., 2002; Barlow and Gisiner, 2006). In addition, marine animals may get habituated to the deterrent signal, which would render the device ineffective. We therefore conclude that deterrent devices are not an effective means of mitigating collisions with any marine animal.

\section{Propeller Guards}

Propeller guards, such as cages and ducts, can be installed around a propeller as a physical boundary between the propeller blades and an animal. The use of propeller guards has not been tested for large whales. Work et al. (2010) tested the ability of propeller guards to protect loggerhead sea turtles from being injured by small vessels. Propeller guards helped to reduce the risk of lethal injury from 40 to $10 \%$ for vessels at idle speed (i.e., 4 knots), but no reduction in risk was seen at planing speed (i.e., 22 knots), because of an increased risk of blunt force trauma. In addition, propeller guards of a different design were not as effective, even at idle speed. These results highlight the need for further research into the best designs for propeller guards. However, in combination with a reduction in speed, propeller guards could effectively reduce sharp force injuries.

\section{Technological Data and Information Systems}

Technological data and information systems have primarily been developed to aid the mitigation of collisions with large whales, although some may also protect smaller species. In general, these systems are used to alert mariners that they are entering an area with a high density of animals prone to collisions (Ward-Geiger et al., 2005), to alert mariners of recent animal sightings (National Marine Fisheries Service, 2005; Ward-Geiger et al., 2005; van Parijs et al., 2009; Souffleurs d'Ecume, 2012; Conserve.iO, 2019), to gather data on vessel abundance and distribution (van der Hoop et al., 2012), and to gather data on vessel compliance with mitigation measures (Lagueux et al., 2011; McKenna et al., 2012; Silber et al., 2014). 


\section{Mandatory Ship Reporting (MSR)}

There are two MSR areas along the eastern U.S. coastline that surround critical North Atlantic right whale habitat: 1 yearround area off the state of Massachusetts and one seasonal area within the SEUS (Ward-Geiger et al., 2005). These measures were adopted by the IMO in 1998 and represent the first involvement of the IMO in implementing measures to protect whales from collisions. The MSR system requires all ships $\geq 300$ gross tonnage to report to a shore-based station when entering the areas. A land-based station stores all incoming ship reports and returns an automated message on steps to avoid collisions with whales (i.e., keep a look-out and reduce speed) as well as recent whale sightings.

MSR systems themselves are not an effective mitigation measure to protect right whales from collisions, but have been regarded as a successful method to educate mariners on ship strike issues and measures to decrease the risk of collision (International Whaling Commission, 2011). MSR systems also provide the opportunity to gather ship transit data (i.e., ship route, ship speed, and primary destinations), which can assist with the development of mitigation measures and assessment of compliance with mitigation measures (Ward-Geiger et al., 2005; Silber et al., 2015). However, ship transit data can now be derived from AIS data for large vessels. We expect the effects of MSR systems to be similar for smaller species. Although MSR systems can help to educate mariners, there are other, less costly ways available to achieve education goals.

\section{Early Warning System (EWS)}

The EWS is an aerial survey network operated within the SEUS (from Georgia, south along the coast of Florida), the Great South Channel, and Cape Cod Bay (Boston, MA) (National Marine Fisheries Service, 2005). The EWS was established to reduce ship strikes with North Atlantic right whales by providing whale sighting information to the U.S. Navy (USN), U.S. Coast Guard (USCG), U.S. Army Corps of Engineers (USACE), harbor pilots, port authorities, and other maritime organizations. Sighting information is subsequently distributed to commercial and recreational vessel crew. If the EWS sights whales near shipping lanes, vessels are requested to reduce their speed and where possible, to undertake avoidance measures to prevent collision with- or serious injury to whales.

There is no evidence that this reporting system has reduced the number of collisions with right whales along the east coast of the U.S. (Lagueux et al., 2011). In addition, aerial surveys are costly as well as restricted to good weather conditions. Furthermore, communication of animal sightings to smaller vessels is challenging because they are often less well-equipped for radio communication. Hence, despite many smaller marine animal species also being visible from aerial surveys (e.g., dolphins, dugongs, manatees, sharks, and even sea turtles: Irvine and Campbell, 1978; Preen, 2000; Kessel et al., 2013; Martins et al., 2013), we do not recommend that these systems are specifically implemented to mitigate vessel collisions. An EWS may work when aerial surveys are already flown for other research purposes. However, solving the issue regarding communication with smaller vessels will require development of alerting systems, such as mobile phone apps (see section Recent mobile phone alerting systems).

\section{Passive Acoustic Buoy Systems}

Passive acoustic buoy systems can be used to improve the detection of marine animals. The Cornell Laboratory of Ornithology and Woods Hole Oceanographic Institution in the U.S. developed a real-time passive acoustic buoy system that specifically recognizes North Atlantic right whale calls (van Parijs et al., 2009). One of these systems is moored to the seafloor along the TSS approaching Boston harbor, where large tankers cross a primary right whale feeding habitat. The buoys listen to whale calls and communicate their data to a shore-based laboratory for whale call verification. All information is forwarded to the right whale Sighting Advisory System (SAS); a multi-institutional effort to monitor right whale populations within northeast U.S. waters. The SAS will alert mariners to the presence of right whales via verbal updates to commercial vessels, 24 -h radio broadcasts, and postings on several websites (van Parijs et al., 2009).

Similar to the EWS, there is currently no evidence that passive acoustic buoy systems help to reduce collision risk. In addition, vocalizations for some species have strong temporal patterns or depend on an individuals' behavior, resulting in inconsistent acoustic detection probabilities (e g., Baumgartner and Fratantoni, 2008; Feng and Bass, 2016; Webster et al., 2019). Furthermore, the detection range of vocalizations is reduced for vocalizations at a higher frequency, thereby reducing the potential effective mitigation range for Odontocete species. For other species, we lack knowledge of their acoustic repertoire (Ferrara et al., 2014). Buoy systems also come at a cost and require regular maintenance to prevent deterioration. Considering these constraints, we recommend that further research be conducted to determine the utility of passive acoustic buoy systems in reducing collision risk.

\section{Real Time Plotting of Cetaceans (REPCET)}

REPCET is a software system developed to reduce ship strikes with whales in the Pelagos Sanctuary (Mediterranean Sea: Mayol et al., 2008; Mayol, 2012) and can be installed on commercial as well as recreational vessels. Once an animal is sighted, the observer inserts the GPS position in the REPCET system, which subsequently transmits the sighting data to a shore-based station. From the shore-based station, the information is sent to other ships equipped with a REPCET system within the sighting area. The onboard receiver automatically processes the data and displays the sightings on a digital map, including an associated risk zone. Each vessel with REPCET will automatically receive a warning signal upon entry of a risk area.

To date, the effectiveness of REPCET in the prevention of collisions has not been verified (Couvat and Mayol, 2014). However, although designed to protect large whales, the system appears to function well in distributing sighting information of both large and small cetaceans to mariners (Couvat and Mayol, 2014). We think it will be valuable to evaluate the effectiveness of REPCET in reducing collision risk with whales and smaller cetaceans, as animal positions are relayed in a seemingly faster manner then via MSR, the EWS, or passive acoustic methods. The 
illustrative display of sightings and automated warning signal may also be an easier and more effective way to encourage mariners to slow down, be cautious, and undertake an avoidance maneuver. However, we are concerned with the use of such systems on small recreational and commercial vessels. These smaller vessels are often attracted to or even specifically aim to view charismatic species (e.g., whale- and dolphin-watching vessels, ecotour vessels, sunset cruises), and may use REPCET to find and potentially harass these animals.

\section{Recent Mobile Phone Alerting Systems}

Mobile technology continuously progresses and has been used to spread information on mitigation measures and animal sightings since 2012. The app "Whale Alert" was the first mobile technology to provide the U.S. shipping industry with information on North Atlantic right whale management areas, required reporting areas, recommended routes, and ATBAs. It also provides near real-time warnings of right whale detections from the passive acoustic buoy system near the Boston TSS (Conserve.iO, 2019). At present, the app is being diversified to include warnings for multiple whale species and to cover a larger geographical area. The sister app "Manatee Alert" alerts boaters to manatee management areas and provides a means to easily report an injured or distressed manatee. In recent years, several other apps (e.g., SpotterPro, Seafari, WhaleReport) have become available that allow people to log marine animal sightings directly from their mobile phone. These applications could potentially be converted into similar alerting systems as "Whale Alert."

At present, it is unknown whether "Whale Alert" or "Manatee Alert" have helped to reduce collision risks with whales and manatees. However, reporting apps do have the potential to aid in voyage planning and to provide information about animal distribution patterns via public reporting (i.e., citizen science). Citizen science data is often characterized by challenges, such as misidentification of species and the absence of effort data. These challenges can be overcome by applying sighting selection criteria (e.g., photo of species, detailed description of species) to decrease species identification biases and by applying background sampling techniques (e.g., including a proxy of human densities) to account for effort biases (Derville et al., 2018). Thus, reporting apps may be useful to identify species hotspots and therefore, assist in the identification of potential high-risk areas. In addition, apps can provide an easy means to report marine animal strandings or sightings of injured animals.

\section{Education and Awareness}

As mentioned under section Mandatory Ship Reporting (MSR), one of the earliest efforts to educate and create awareness with mariners about collision risks was the broadcasting of messages via the MSR system. Since then, education and creating awareness initiatives have been started globally. Global efforts have been undertaken by the IMO, who published a collision guidance document that member governments were encouraged to circulate further to stakeholders and interested parties (International Maritime Organization, 2009). The IWC is putting continuous efforts into global public outreach initiatives, which have been a topic of attention since the start of the
SSWG (International Whaling Commission, 2007). While global efforts will ensure that mariners receive consistent information about collision risks, it can take a considerable amount of time to compose and distribute internationally relevant data. Hence, local efforts to educate mariners on the risk of collision with a specific species or within a specific area are a faster way to create awareness and help mitigate collisions in local hotspots. An example of a more localized effort is the development of an education module for maritime academies, as well as certification and licensing courses, by the New England Aquarium under a contract issued by the NMFS in 2003. This module aims to educate vessel officers and crew about the potential for vessel strikes with North Atlantic right whales and the regulatory measures in place to protect these whales (Knowlton et al., 2007). The merchant marine trainer module has been introduced to various marine academies in the U.S. as well as to international maritime schools that are likely to train mariners who transit the east coast of the U.S. and Canada (Knowlton et al., 2007). Identifying and evaluating these types of programs for use on a wider scale or for other marine user groups is included in the latest IWC strategic plan (Cates et al., 2017). In New Zealand, a special Bryde's whale ship strike working group has been established to investigate and share information on the cause of ship strikes with Bryde's whales as well as to develop and discuss feasible mitigation measures (Constantine et al., 2015). This working group includes individuals from industry, government, academic institutions, non-government organizations, and local Mãori tribes. During a joint ACCOBAMS/Pelagos workshop, shipping company representatives highlighted the importance of educating captains and vessel crew on the risk of collision (Weinrich et al., 2005).

Education is the fundamental basis for the implementation of mitigation measures and for compliance with regulations, because people need to understand the risk to animals, vessels, and vessel crew as well as the locations where vessel crew are likely to encounter marine animals, and what they can do to avoid a collision (Ritter, 2012; Flamm and Braunsberger, 2014). It is difficult to assess quantitatively how education and awareness reduce collision risk, but it is generally known that education leads to active engagement. We therefore suggest that more effort is dedicated to creating awareness about collision risks with marine animals, regardless of species. Whether education efforts are developed globally or locally should depend on factors, such as the species distribution, number of locations in which a species is at risk of collision, and types of vessels involved in collisions.

\section{ISSUES AND KNOWLEDGE GAPS Assessing the Extent of Collision Incidences}

A total of 75 marine species have been identified to collide with marine vessels, which illustrates that collisions with marine life may comprise a much larger problem than initially thought. However, for most smaller species, we know little about the extent of collision incidences. This knowledge gap should be addressed. Most collision reports involving smaller species were 
based on signs of sharp force trauma. Although differences in the most prevalent trauma may exist between species, it is highly unlikely that smaller marine species are not subject to blunt force injury. The absence of blunt force trauma suggests that the information needed to identify this type of trauma in smaller species may be absent, which would result in an underreporting of collision incidents. Detailed criteria have been developed for the identification of both sharp and blunt force trauma in whales and manatees as well as for sharp force injuries in dolphins, seals, and sea turtles (Moore et al., 2013; Foley et al., 2019). However, there is a need to develop species-specific necropsy protocols that will allow for the identification of collision-related blunt force trauma in smaller species.

The next step is to establish an international collision database for smaller marine species, as has been done by the IWC for whales. The IWC database has been shown to be a valuable tool for identifying the species most affected, vessels involved in collisions, and correlations between vessel speed and collision risk (Jensen and Silber, 2003). Hence, establishing a database for other marine species could provide similar valuable information. Unlike large whales, many populations of smaller species are at risk of collision within smaller geographic regions. We therefore think that the establishment of a database for small species will work best via mandatory and standardized reporting protocols that are implemented and managed by government authorities. Local databases should then annually be submitted to an international database.

\section{Long-Term Consequences of Collisions}

Injuries relocate energy from growth and reproduction to body maintenance (van der Meer, 2006), but there is a lack of information on how non-fatal injuries affect individual fitness over prolonged timeframes. In addition, for many populations it is unknown how collision-related mortality contributes to the overall mortality rate. There is an urgent need to move beyond the quantification of the type of injury and to assess population level consequences. Once we can begin to assess population consequences, we will then be able to consider how these consequences affect ecosystem structure, function, and stability (Wong and Candolin, 2015).

\section{The Risk of Collision}

The identification of high-risk areas is an important step toward the implementation of mitigation measures, but has so far focussed on whales. In addition, the identification of high-risk areas is likely biased because of global information gaps on vessel as well as animal abundance and distribution. The distribution and abundance of smaller vessels is poorly understood because they do not have to use designated shipping lanes and are not required to carry an AIS transponder that transmits their position (Lagueux et al., 2011). A lack of data on small vessel distribution patterns prohibits the identification of high-risk areas for coastal species. A long-term option to trace small vessels could comprise mandatory installation of simple, cost-effective, GPS-tracking systems on small vessels to monitor general movement patterns. However, implementation of such a system will take time. A quicker solution could be to start simultaneous surveys on animal and small vessel distribution patterns in areas where collisions are frequently reported or in coastal areas where species aggregations are known to overlap with vessel traffic. Identified Important Marine Mammal Area's (IMMAs: discrete portions of habitat, important to marine mammal species, that have the potential to be delineated and managed for conservation) may be a good starting point to identify high-risk areas for smaller marine mammals (International Whaling Commission, 2019a).

As mentioned under section "Assessing the extent of collision incidences", assessment of the extent of collision events and factors affecting the risk of collision can be facilitated by an international database (Jensen and Silber, 2003). Currently there is not enough information about smaller marine species to model collision risk as a function of vessel speed and to assess which types of vessels collide with smaller species. However, it should be highlighted that collisions with large vessels are unlikely to be reported, regardless of the establishment of a comprehensive database, because crew on these vessels will be unaware of collisions with smaller species. Reporting biases should be considered when making inference from a collision database (Peel et al., 2018).

\section{Mitigation Measures}

Two mitigation measures have been identified to successfully mitigate collisions with whales: re-routing of vessel traffic around areas of greatest relative risk and a reduction in vessel speed. Similar mitigation measures will be effective for the protection of other marine species. Several studies have highlighted the non-compliance of smaller vessels with mitigation measures unless there is enforcement (Gorzelany, 2004; Jett and Thapa, 2010). Successful mitigation of collisions with smaller species therefore requires careful consideration of methods to ensure that compliance is high. Education and enforcement are key to compliance. Education can start with handing out information brochures when issuing skippers tickets or permits to operate in specific areas.

It should be highlighted that animals may change their distribution, timing of migration, expand their range etc. Thus, a constant re-evaluation of implemented mitigation strategies is important (Record et al., 2019). More information is needed about unintended consequences as well as potential benefits associated with the implementation of specific mitigation measures. A reduction in vessel speed, reduces the risk of lethal injury, greenhouse gas emissions, and noise at low frequencies (10-100 Hz) (Joy et al., 2019; Leaper, 2019). However, lower speeds also result in increased transit times and may result in a higher probability of a collision for species that do not avoid vessels (Gerstein et al., 2005; Martin et al., 2016). In addition, reduced vessel speeds reduce noise at higher frequencies (10$100 \mathrm{kHz}$ ) less effectively and may therefore result in prolonged exposure with consequent negative effects on species sensitive to high frequency noise (Joy et al., 2019). There is also a paucity of information on how mitigation measures implemented to protect one species affect other species within the same area. Rerouting vessel traffic around one species habitat, for example, may increase risk to a different species (Redfern et al., 2013; Ritter et al., 2019). 
Which mitigation measures should be applied depends on the species involved, other species within the area, vessel traffic (i.e., predictability and manageability), the geographic and environmental features of the area, and the economic impacts of the mitigation measure (Laist and Shaw, 2006; Couvat and Gambaiani, 2013; Constantine et al., 2015). The effectiveness of mitigation measures depends on their design and the level of compliance. Selection of effective mitigation measures requires a multi-species approach and active interactions between relevant stakeholders so that individual priorities can be identified and addressed (Constantine et al., 2015; Redfern et al., 2019).

\section{CONCLUSIONS}

To date, most scientific publications on collisions have focused on the interactions between large vessels and large whales. Consequently, over the years we have gained valuable insights on the risk of collision to large whales as well as how to effectively mitigate collisions with large whales. Our review found that at least 75 marine species, including smaller whales, dolphins, porpoises, dugongs, manatees, whale sharks, sharks, seals, sea otters, turtles, penguins, and fish have collided with vessels. To date, data on collisions with smaller marine species is scarce, which is likely more a result of reporting biases than a reflection of the true extent of the collision problem. Reliable reporting requires the establishment of species-specific necropsy protocols to accurately identify collision-related injury and

\section{REFERENCES}

Abdulla, A., and Linden, O. (2008). Maritime traffic effects on biodiversity in the Mediterranean Sea: Review of impacts, priority areas and mitigation measures. Malaga: IUCN Centre for Mediterranean Cooperation.

Ackerman, B. B., Wright, S. D., Bonde, R. K., O’Dell, D. K., and Banowetz, D. J. (1995). "Trends and patterns in mortality of manatees in Florida 19741992," in Population Biology of the Florida Manatee, eds T. J. O'Shea, B. B. Ackerman, and H. F. Percival (Washington, DC: National Biological Service), 223-258.

Agreement on the Conservation of Small Cetaceans of the Baltic and North Seas (2011). Report of the Joint IWC-ACCOBAMS Workshop on Reducing Risk of Collisions Between Vessels and Cetaceans. Document AC18/Doc.5-08 presented at the 18th ASCOBANS advisory committee meeting held in Bonn.

Allen, B. M., and Angliss, R. P. (2013). Alaska Marine Mammal Stock Assessments 2012 [NOAA Technical Memorandum NMFS-AFSC-245. Springfield, VA; US Department of Commerce].

Allen, J. K., Peterson, M. L., Sharrard, G. V., Wright, D. L., and Todd, S. K. (2012). Radiated noise from commercial ships in the Gulf of Maine: implications for whale/vessel collisions. J. Acoust. Soc. Am. 132, 229-235. doi: 10.1121/1.4739251

Alzueta, J. C., Flórez-González, L., and Fernández, P. F. (2001). Mortality and anthropogenic harassment of humpback whales along the Pacific coast of Colombia. Mem. Queensl. Mus. 47, 547-553.

Arbelo, M., de los Monteros, A. E., Herráez, P., Andrada, M., Sierra, E., Rodríguez, F., et al. (2013). Pathology and cause of death of stranded cetaceans in the Canary Islands (1999-2005). Dis. Aqu. Organ. 103, 87-99. doi: 10.3354/dao02558

Arregui, M., de Quirós, Y. B., Saavedra, P., Sierra, E., Suárez-Santana, C., Arbelo, M., et al. (2019). Fat embolism and sperm whale ship strikes. Front. Mar. Sci. 6:379. doi: 10.3389/fmars.2019.00379 mortality, especially for blunt-force trauma. The establishment of an international standardized database, like the IWC database for large whales, could aid in filling information gaps on frequency of collisions, vessels involved, and potential high-risk areas for smaller species. In addition, technology and research are needed to estimate risk in areas used by smaller vessels, smaller species, and less well-studied species. Prioritizing these three areas (i.e., species-specific necropsy protocols, a database for smaller species, and identification of high-risk areas for smaller species) would be a valuable step toward the mitigation of collisions with species other than large whales.

\section{AUTHOR CONTRIBUTIONS}

RS conceived and designed the study, collected and analyzed the literature, produced the tables and figures, authored and reviewed the drafts of the manuscript, and approved the final manuscript. CP-A produced the tables and figures, reviewed the drafts of the manuscript, and approved the final manuscript. SP conceived and designed the study, reviewed the drafts of the manuscript, and approved the final manuscript.

\section{ACKNOWLEDGMENTS}

We acknowledge Dr. Michael J. Moore, Dr. Moira Brown, Dr. Thibaut Bouveroux, Dr. Simone Panigada, Prof. Christine Erbe and the three reviewers for insightful comments on an earlier draft of this manuscript.

Ávila-Canto, J. G., Velázquez-Mendoza, C., Castelblanco-Martínez, N., NiñoTorres, C., and Córdova-Tapia, F. (2017). Is the antillean manatee (Trichechus manatus manatus) back in town? Presence of the species at the "Área de Protección de Flora y Fauna Yum Balam”, Quintana Roo, Mexico. Rev. Mex. Biodivers. 88, 999-1002. doi: 10.1016/j.rmb.2017.10.036

Balazik, M. T., Reine, K. J., Spells, A. J., Fredrickson, C. A., Fine, M. L., Garman, G. C., et al. (2012). The potential for vessel interactions with adult Atlantic sturgeon in the James River, Virginia. Normal Am. J. Fish. Manage. 32, 1062-1069. doi: 10.1080/02755947.2012.716016

Barber, D. G., Richard, P. R., Hochheim, K. P., and Orr, J. (1991). Calibration of aerial thermal infrared imagery for walrus population assessment. Arctic 44, 58-65. doi: 10.14430/arctic1571

Barcenas-De la Cruz, D., DeRango, E., Johnson, S. P., and Simone, C. (2017). Evidence of anthropogenic trauma in marine mammals stranded along the central California coast, 2003-2015. Mar. Mamm. Sci. 34, 330-346. doi: $10.1111 / \mathrm{mms} .12457$

Barlow, J., and Gisiner, R. (2006). Mitigating, monitoring and assessing the effects of anthropogenic sound on beaked whales. J. Cetac. Res. Manage. 7, 239-249.

Baumgartner, M. F., and Fratantoni, D. M. (2008). Diel periodicity in both sei whale vocalisation rates and the vertical migration of their copepod prey observed from ocean gliders. Limnol. Oceanogr. 53, 2197-2209. doi: 10.4319/lo.2008.53.5_part_2.2197

Bechdel, S. E., Mazzoil, M. S., Murdoch, M. E., Howells, E. M., Reif, J. S., McCulloch, S. D., et al. (2009). Prevalence and impacts of motorized vessels on bottlenose dolphins (Tursiops truncatus) in the Indian River Lagoon, Florida. Aquat. Mamm. 35, 367-377. doi: 10.1578/AM.35.3.2009.367

Beck, C. A., Bonde, R. K., and Rathbun, G. B. (1982). Analyses of propeller wounds on manatees in Florida. J. Wildl. Manag. 46, 531-535.

Bejder, L., Videsen, S., Hermannsen, L., Simon, M., Hanf, D., and Madsen, P. T. (2019). Low energy expenditure and resting behaviour of humpback whale mother-calf pairs highlights conservation importance 
of sheltered breeding areas. Sci. Rep. 9:771. doi: 10.1038/241598-01836870-7

Berman-Kowalewski, M., Gulland, F. M. D., Wilkin, S., Calambokidis, J., Mate, B., Cordaro, J., et al. (2010). Association between blue whale (Balaenoptera musculus) mortality and ship strikes along the California coast. Aquat. Mamm. 36, 59-66. doi: 10.1578/AM.36.1.2010.59

Best, P. B., Peddemors, V. M., Cockcroft, V. G., and Rice, N. (2001). Mortalities of right whales and related anthropogenic factors in South African waters, 1963-1998. J. Cetacean Res. Manag. 2, 171-176.

Bezamat, C., Wedekin, L. L., and Simões-Lopes, P. C. (2014). Potential ship strikes and density of humpback whales in the Abrolhos Band breeding ground, Brazil. Aquat. Conserv. 25, 712-725. doi: 10.1002/aqc.2523

Bloom, P., and Jager, M. (1994). The injury and subsequent healing of a serious propeller strike to a wild bottlenose dolphin (Tursiops truncatus) resident in cold waters off the Northumberland coast of England. Aquat. Mamm. 20, 59-64.

Bogomolni, A. L., Pugliares, K. R., Sharp, S. M., Patchett, K., Harry, C. T., LaRocque, J. M., et al. (2010). Mortality trends of stranded marine mammals on Cape Cod and southeastern Massachusetts, USA, 2000 to 2006. Dis. Aquat. Organ. 88, 143-155. doi: 10.3354/dao02146

Borsa, P. (2006). Marine mammal strandings in the New Caledonia region, Southwest Pacific. C R Biol. 329, 277-288. doi: 10.1016/j.crvi.2006.01.004

Bradford, A. L., Weller, D. W., Ivashchenko, Y. V., Burdin, A. M., and Brownell, J. R. (2009). Anthropogenic scarring of western gray whales (Eschrichtius robustus). Mar. Mamm. Sci. 25, 161-175. doi: $10.1111 / j .1748-7692.2008 .00253 . x$

Brown, J. J., and Murphy, G. W. (2010). Atlantic sturgeon vessel-strike mortalities in the Delaware estuary. Fisheries 35, 72-83. doi: 10.1577/1548-8446-35.2.72

Burn, D. M., Udevitz, M. S., Speckman, S. G., and Benter, R. B. (2009). An improved procedure for detection and enumeration of walrus signatures in airborne thermal imagery. Int. J. Appl. Earth Observ. 11, 324-333. doi: 10.1016/j.jag.2009.05.004

Byard, R. W., Winskog, C., Machado, A., and Boardman, W. (2012). The assessment of lethal propeller strike injuries in sea mammals. J. Forensic Leg. Med. 19, 158-161. doi: 10.1016/j.jflm.2011.12.017

Calleson, C. S., and Frohlich, R. K. (2007). Slower boat speeds reduce risks to manatees. Endanger. Species Res. 3, 295-304. doi: 10.3354/esr00056

Camargo, F. S., and Bellini, C. (2007). Report on the collision between a spinner dolphin and a boat in the Fernando de Noronha Archipelago, Western Equatorial Atlantic, Brazil. Biota Neotrop. 7, 210-211. doi: 10.1590/S1676-06032007000100024

Campbell-Malone, R., Barco, S. G., Daoust, P. Y., Knowlton, A. R., McLellan, W. A., Rotstein, D. S., et al. (2008). Gross and histologic evidence of sharp and blunt trauma in North Atlantic right whales (Eubalaena glacialis) killed by vessels. J. Zool. Wildl. Med. 39, 37-55. doi: 10.1638/2006-0057.1

Camphuysen, C. J., and Siemensma, M. L. (2011). "Conservation Plan For The Harbour Porpoise Phocoena Phocoena," in The Netherlands: Towards A Favourable Conservation Status NIOZ Report 2011-07. Texel: Royal Netherlands Institute for Sea Research.

Cannell, B. L., Campbell, K., Fitzgerald, L., Lewis, J. A., Baran, I. J., and Stephens, N. S. (2016). Anthropogenic trauma is the most prevalent cause of mortality in Little Penguins, Eudyptula minor, in Perth, Western Australia. Emu Aust. Ornithol. 116, 52-61. doi: 10.1071/MUI5039

Cannon, A. C. (1998). Gross Necropsy Results of Sea Turtles Stranded on the Upper Texas and Western Louisiana Coasts, 1 January-31 December 1994. NOAA Technical Report NMFS 143. Springfield, VA: US Department of Commerce.

Cardona, L., Fernández, G., Revelles, M., and Aguilar, A. (2012). Readaptation to the wild of rehabilitated loggerhead sea turtle (Caretta caretta) assessed by satellite telemetry. Aquat. Conserv. 22, 104-122. doi: 10.1002/ aqc/1242

Carretta, J. V., Forney, K. A., Oleson, E., Martien, K., Muto, M. M., Lowry, M. A., et al. (2012). US Pacific Marine Mammal Stock Assessments: 2011. NOAA Technical Memorandum NOAA-TM-NMFS-SWFSC-488. Springfield, VA: US Department of Commerce.

Carrillo, M., and Ritter, F. (2010). Increasing numbers of ship strikes in the Canary Islands: proposals for immediate action to reduce risk of vessel-whale collisions. J. Cetacean. Res. Manage. 11, 131-138.
Carrillo, M., and Taverna, A. (2011). "Collisions between ships and whales in the Canary Islands. The case of Tenerife," Paper Presented at the Workshop on Reducing Risk of Collisions Between Vessels and Cetaceans (Beaulieu sur Mer).

Casale, P., Affronte, M., Insacco, G., Freggi, D., Vallini, C., D’Astore, P. P., et al. (2010). Sea turtle strandings reveal high anthropogenic mortality in Italian waters. Aquat. Conserv. 20, 611-620. doi: 10.1002/aq c. 1133

Cates, K., DeMaster, D. P., Brownell, R. L. Jr, Silber, G., Gende, S., et al. (2017). Strategic Plan to Mitigate the Impacts of Ship Strikes on Cetacean Populations: 2017-2020. IWC Strategic Plan to Mitigate Ship Strikes. Jersey: International Whaling Commission.

Chaloupka, M., Work, T. M., Balazs, G. H., and Murakawa, K. K. (2008), Cause-specific temporal and spatial trends in green sea turtle strandings in the Hawaiian Archipelago (1982-2003). Mar. Biol. 154, 887-898. doi: 10.1007/s00227-008-0981-4

Chion, C., Turgeon, S., Cantin, G., Michaud, R., Ménard, N., Lesage, V., et al. (2018). A voluntary conservation agreement reduces the risks of lethal collisions between ships and whales in the St. Lawrence Estuary (Québec, Canada): from co-construction to monitoring compliance and assessing effectiveness. PLoS ONE 13:e0202560. doi: 10.1371/journal.pone.0202560

Clarey, C. (2014). In Ocean Races, Some of the Biggest Perils Can't Be Seen. Available at: http://www.nytimes.com/2014/12/24/sports/sydney-hobartyacht-race-dangers-for-sailors.html?_r=0 (Accessed May 31, 2019).

Clifton, K. B., Yan, J., Mecholsky, J. J. Jr., and Reep, R. L. (2008). Material properties of manatee rib bone. J. Zool. 274, 150-159. doi: 10.1111/j.1469-7998.2007.00366.x

Combs, B. L. (2018). Quantifying the probability of lethal injury to Florida manatees given characteristics of collision events (MSc thesis). Tampa, FL: University of South Florida.

Common Wealth of Australia (2017). National Strategy for Reducing Vessel Strike on Cetacean and Other Marine Megafauna. Canberra; NSW: Australian Government, Department of the Environment and Energy.

Conn, P. B., and Silber, G. K. (2013). Vessel speed restrictions reduce risk of collision-related mortality for North Atlantic right whales. Ecosphere 4:43. doi: 10.1890/ES13-00004.1

Conserve.iO (2019). Conserve.iO. Apps for a Better Planet. Conserve.iO. Available online at: http://conserve.io/ (accessed May 31, 2019).

Constantine, R., Johnson, M., Riekkola, L., Jervis, S., Kozmian-Ledward, L., Dennis, T., et al. (2015). Mitigation of vessel-strike mortality of endangered Bryde's whales in the Hauraki Gulf, New Zealand. Biol. Conserv. 186, 149-157. doi: 10.1016/j.biocon.2015.03.008

Couvat, J., and Mayol, P. (2014). REPCET Observation Report 2013. La Celle: Souffleurs d'Ecume.

Couvat, L., and Gambaiani, D. (2013). Evaluation of the Technical Solutions and Management Measures Implemented at the International Level to Reduce the Risks of Collisions Between Ships and Large Cetaceans. La Celle: Souffleurs d'Ecume.

Crum, N., Gowan, T., Krzystan, A., and Martin, J. (2019). Quantifying risk of whale-vessel collisions across space, time, and management policies. Ecosphere 10:e02713. doi: 10.1002/ecs2.2713

Currey, R. J. C. (2008). Conservation biology of bottlenose dolphins in fiordland, New Zealand (Ph.D.). University of Otago, Dunedin, New Zealand. Available online at: https://ourarchive.otago.ac.nz/bitstream/handle/10523/129/Currey $\% 20 \mathrm{PhD} \% 202008 \% 20$ Low\%20Res.pdf? sequence=1\&isAllowed=y (accessed on October 12, 2019).

Currie, J. J., Stack, S. H., and Kaufman, G. D. (2017). Modelling whale-vessel encounters: the role of speed in mitigating collisions with humpback whales (Megaptera novaeangliae). J. Cetac. Res. Manage. 17, 57-64.

Cusano, D. A., Conger, L. A., van Parijs, S. M., and Parks, S. E. (2019). Implementing conservation measures for the North Atlantic right whale: considering the behavioural ontogeny of mother-calf pairs. Ani. Conserv. 22, 228-237. doi: 10.1111/acv.12457

Cuyler, L. C., Wiulsrød, R., and ØRitsland, N. A. (1992). Thermal infrared radiation from free living whales. Mar. Mamm. Sci. 8, 120-134. doi: 10.1111/j.1748-7692.1992.tb00371.x

da Costa Toledo, G. A., Furni, F. R. G., Ferreira, P. H. P., Garcia, F. C. P., Ferreira, R. G., and Sousa-Lima, R. S. (2017). Epimeletic behaviour of Guiana dolphins 
(Sotalia guianensis) towards a calf supposedly killed by a motorboat in Brazil. Aquat. Mamm. 43, 614-617. doi: 10.1578/AM.43.6.2017.614

Dalebout, M. L., Russell, K. G., Little, M. J., and Ensor, P. (2004). Observations of live Gray's beaked whales (Mesoplodon grayi) in Mahurangi harbour, North Island, New Zealand, with a summary of at-sea sightings. J. R. Soc. New Zeal. 34, 347-356. doi: 10.1080/03014223.2004.9517771

Davenport, J., and Davenport, J. L. (2006). The impact of tourism and personal leisure transport on coastal environments: a review. Estuar. Coast. Shelf Sci. 67, 280-292. doi: 10.1016/j.ecss.2005.11.026

David, L., Alleaume, S., and Guinet, C. (2011). Evaluation of the potential of collision between fin whales and maritime traffic in the North-western Mediterranean Sea in summer, and mitigation solutions. J. Mar. Anim. Ecol. $4,17-28$.

Davies, K. T. A., and Brillant, S. W. (2019). Mass human-caused mortality spurs federal action to prevent endangered North Atlantic right whales in Canada. Mar. Policy 104, 157-162. doi: 10.1016/j.marpol.2019. 02.019

de Vere, A. J., Lilley, M. K., and Frick, E. E. (2018). Anthropogenic impacts on the welfare of wild marine mammals. Aquat. Mamm. 44, 150-180. doi: 10.1578/AM.44.2.2018.150

de Vos, A., Wu, T., and Brownell, Jr. R.L. (2013). "Recent blue whale deaths due to ship strikes around Sri Lanka" Paper SC/65A/HIM03 Discussed at the Annual Scientific Committee Meeting held in Korea in 2013. Cambridge, UK: International Whaling Commission.

Deaville, R., Jepson, P. D., Perkins, M., Brownlow, A., Davidson, N., ten Doeschate, M., et al. (2018). Final Contract Report $1^{\text {st }}$ January 2011 to 31 $1^{\text {st }}$ December 2017. Report MB0111 2011-2017 by the UK Cetacean Strandings Investigation Programme to Defra. Available online at: https://www.google.com/url?sa $=$ t\&rct $=j \& q=\& e s r c=s \&$ source $=$ web\&cd $=$ $1 \&$ ved=2ahUKEwj2z4-M0czlAhVOzqQKHdMtB6kQFjAAegQIAhAC\& url=http\%3A\%2F\%2Fsciencesearch.defra.gov.uk\%2FDocument.aspx \%3FDocument\%3D14514_FINALCSIPContractReport2011-2017.pdf\& usg=AOvVaw0MFFzOybYyTEQuB6UMkxlm (accessed on October 10, 2019)

Deem, S. L., Dierefeld, E. S., Sounguet, G. P., Allen, A. R., Cray, C., Poppenga, R. H., et al. (2006). Blood values in free-ranging nesting leatherback sea turtles (Dermochelys coriacea) on the coast of the Republic of Gabon. J. Zoo Wildl. Med. 37, 464-471. doi: 10.1638/05-102.1

Denkinger, J., Parra, M., Muñoz, J. P., Carrasco, C., Murillo, J. C., Espinosa, E., et al. (2013). Are boat strikes a threat to sea turtles in the Galapagos Marine Reserve? Ocean Coast Manage. 80, 29-35. doi: 10.1016/j.ocecoaman.2013.03.005

Department of Parks and Wildlife (2013). Whale Shark Management With Particular Reference to Ningaloo Marine Park. Wildlife Management Program no. 57. Perth, WA: Department of Parks and Wildlife.

Derville, S., Torres, L. G., Iovan, C., and Garrigue, C. (2018). Finding the right fit: comparative cetacean distribution model using multiple data sources and statistical approaches. Divers. Distrib. 24, 1657-1673. doi: 10.1111/ddi.12782

Díaz-Delgado, J., Fernández, A., Sierra, E., Sacchini, S., Andrada, M., Vela, A. I., et al. (2018). Pathologic findings and causes of death of stranded cetaceans in the Canary Islands (2006-2012). PLoS ONE 13:e0204444. doi: $10.1371 /$ journal/pone/0204444

DiMaio, V. K., and DiMaio, D. (2001). Forensic Pathology 2nd Edn. Boca Raton, FL: CRC Press, Inc.

Di-Méglio, N., David, L., and Monestiez, P. (2018). Sperm whale ship strikes in the Pelagos Sanctuary and adjacent waters: assessing and mapping collision risks in summer. J. Cetac. Res. Manage. 18, 135-147.

Dolman, S., Williams-Grey, V., Asmutis-Silvia, R., and Isaac, S. (2006). Vessel Collisions and Cetaceans: What Happens If They Don't Miss the Boat. Science Report. Wiltshire: Whale and Dolphin Conservation Society.

Douglas, A. B., Calambokidis, J., Raverty, S., Jeffries, S. J., Lambourn, D. M., and Norman, S. A. (2008). Incidence of ship strikes of large whales in Washington State. J. Mar. Biol. Assoc. 88, 1121-1132. doi: 10.1017/S0025315408000295

Duffus, D. A., and Dearden, P. (1993). Recreational use, valuation, and management, of killer whales (Orcinus orca) on Canada's Pacific coast. Environ. Conserv. 20, 149-156. doi: 10.1017/S0376892900037656

Dukas, R. (2002). Behavioural and ecological consequences of limited attention. Philos. T. R. Soc. B. 357, 1539-1547. doi: 10.1098/rstb.2002.10063

Dwyer, S. L., Kozmian-Ledward, L., and Stockin, K. A. (2014). Short-term survival of severe propeller strike injuries and observations on wound progression in a bottlenose dolphin. New Zeal. J. Mar. Fresh. 48, 394-302. doi: 10.1080/00288330.2013.866578

Edwards, H. H., Martin, J., Deutsch, C. J., Muller, R. G., Koslovsky, S. M., Smith, A. J., et al. (2016). Influence of manatees' diving on their risk of collision with watercraft. PLOS ONE 11:e151450. doi: 10.1371/journal.pone.0151450

Elwen, S. H., and Leeney, R. H. (2010). Injury and subsequent healing of a propeller strike injury to a Heaviside's dolphin (Chephalorhynchus heavisidii). Aquat. Mamm. 36, 382-387. doi: 10.1578/AM.36.4.2010.382

Erbe, C., Reichmuth, C., Cunningham, K., Lucke, K., and Dooling, R. (2016). Communication masking in marine mammals: a review and research strategy. Mar. Pollut. Bull. 102, 15-38. doi: 10.1016/j.marpolbul.2015.12.007

Evans, P. G. H., Baines, M. E., and Anderwald, P. (2011). Risk Assessment of Potential Conflicts Between Shipping and Cetaceans in the ASCOBANS Region. Progress report submitted by the secretariat of the Sea Watch Foundation to the ASCOBANS Advisory Committee.

Fais, A., Lewis, T. P., Zitterbart, D. P., Álvarez, O., Tejedor, A., and Soto, N.A. (2016). Abundance and distribution of sperm whales in the Canary Islands: can sperm whales in the archipelago sustain the current level of ship-strike mortalities? PLoS ONE 11:e0150660. doi: 10.1371/journal.pone.01 50660

Federal Register (2008). Endangered fish and wildlife: final rule to implement speed restrictions to reduce the threat of ship collisions with North Atlantic right whales (50 CFR Part 224). Fed. Regist. 73, 60173-60191

Félix, F., Centeno, R., Romero, J., Zavala, M., and Vásconez, Ó. (2018). Prevalance of scars of anthropogenic origin in coastal bottlenose dolphin in Ecuador. J. Mar. Biol. Assoc. 98, 1177-1186. doi: 10.1017/S0025315417000686

Félix, F., and van Waerebeek, K. (2005). Whale mortality from ship strikes in Ecuador and West Africa. Latin Am. J. Aquat. Mamm. 4, 55-60. doi: $10.5597 /$ lajam00070

Feng, N. Y., and Bass, A. H. (2016). "Singing" fish rely on circadian rhythm and melatonin for the timing of nocturnal courtship vocalization. Curr. Biol. 26, 1-9. doi: 10.1016/j.cub.2016.07.079

Fenton, H., Daoust, P. Y., Forzán, M. J., Vanderstichel, R. V., Ford, J. K. B., Spaven, L., et al. (2017). Causes of mortality of harbour porpoises Phocoena phocoena along the Atlantic and Pacific coasts of Canana. Dis. Aquat. Organ. 122, 171-183. doi: $10.3354 /$ dao0 03080

Ferrara, C. R., Vogt, R. C., Harfush, M. R., Sousa-Lima, R. S., Albavera, E., and Tavera, A. (2014). First evidence of leatherback turtle (Dermochelys coriacea) embryos and hatchlings emitting sounds. Chelon. Conserv. Biol. 13, 110-114. doi: $10.2744 /$ CCB-1045.1

Fertl, D. (1994). Occurrence patterns and behavior of bottlenose dolphins (Tursiops truncatus) in the Galvestone ship channel, Texas. Texas J. Sci. 46, 299-318.

Figueiredo, G. C., Santos, M. C., de, O., Siciliano, S., and Moura, J.F. (2017). Southern right whales (Eubalaena australis) in an urbanized area off the southwestern Atlantic Ocean: updated records and conservation issues. Aquat. Mamm. 43, 52-62. doi: 10.1578/AM.43.1.2017.52

Flamm, R. O., and Braunsberger, K. (2014). Applying marketing to conservation: a case study on encouraging boater reporting of watercraft collisions with Florida manatees. Ocean Coastal Manage. 96, 20-28. doi: 10.1016/j.ocecoaman.2014.04.026

Florida Fish and Wildlife Conservation Committee (2018). Collier County Manatee Protection Areas. Tallahasee, FL: Fish and Wildlife Conservation Committee Division of Habitat and Species Conservation Imperiled Species Management Section. Available online at: https://myfwc.com/media/7294/colliermpz-maps. pdf (accessed on September 12, 2019).

Flynn, K. R., and Calambokidis, J. (2019). Lessons from placing an observer on commercial cargo ships off the US West coast: utility as an observation platform and insight into ship strike vulnerability. Front. Mar. Sci. 6:501. doi: 10.3389/fmars.2019.00501

Foley, A. M., Stacy, B. A., Hardy, R. F., Shea, C. P., Minch, K. E., and Schroeder, B. A. (2019). Characterizing watercraft-related mortality of sea turtles in Florida. J. Wildl. Manage. 83, 1057-1072. doi: 10.1002/ jwmg. 21665

Fonnesbeck, C. J., Garrison, L. P., Ward-Geiger, L. I., and Baumstark, R. D. (2008). Bayesian hierarchichal model for evaluating the risk of vessel strikes on North Atlantic right whales in the SE United States. Endanger. Species Res. 6, 87-94. doi: $10.3354 /$ esr00134 
Ford, J. K. B., Ellis, G. M., and Balcomb, K. C. (2000). Killer whales: The natural history and genealogy of Orcinus orca in British Columbia and Washington State. Seattle, WA: University of Washington Press.

Frantzis, A., Leaper, R., Alexiadou, P., Prospathopoulos, A., and Lekkas, D. (2019). Shipping routes through core habitat of endangered sperm whales along the Hellenic Trench, Greece: can we reduce collision risks? PLoS ONE 14:e0212016. doi: 10.1371/journal.pone.0212016

Freedman, R., Herron, S., Byrd, M., Birney, K., Morten, J., Shafritz, B., et al. (2017). The effectiveness of incentivized and non-incentivized vessel speed reduction programs: case study in the Santa Barbara channel. Ocean Coast. Manag. 148, 31-39. doi: 10.1016/j.ocecoaman.2017. 07.013

Gende, S. M., Hendrix, A. N., Harris, K. R., Eichenlaub, B., Nielsen, J., and Pyare, S. (2011). A Bayesian approach for understanding the role of ship speed in whale-ship encounters. Ecol. Applic. 21, 2232-2240. doi: 10.1890/10-1965.1

George, J. C., Philo, L. M., Hazard, K., Withrow, D., Carroll, G. M., and Suydam, R. (1994). Frequency of killer whale (Orcinus orca) attacks and ship collisions based on scarring on bowhead whales (Balaena mysticetus) of the Bering-Chukchi-Beaufort Seas stock. Arctic 47, 247-255. doi: 10.14430/arct ic 1295

Gerle, E., and DiGiovanni, R. (1998). "An evaluation of human impacts and natural versus human induced mortality in sea turtles in the New York Bight," in Proceedings of the Seventeenth Annual Sea Turtle Symposium, eds S. P. Epperly, and J. Braun (Miami, FL: National Marine Fisheries Service), 187-189.

Gerstein, E., Blue, J., and Forsythe, S. (2005). Ship strike acoustics. J. Acoust. Soc. Am. 117, 2526-2526. doi: 10.1121/1.4788386

Gerstein, E., and Blue, J. E. (2004). Investigation of the Potential Utility of Manatee Alerting Devices, Phase One: acoustic warning System to Alert Manatees of Approaching Vessels. Final report submitted to the Florida Fish and Wildlife Conservation Committee and the Florida Inland Navigation District.

Gerstein, E. R. (2002). Manatees, bioacoustics and boats. Am. Sci. 90, 154-163. doi: $10.1511 / 2002.2 .154$

Gerstein, E. R., and Gerstein, L. A. (2017). Environmentally friendly parametric alarm for alerting marine mammals of approaching vessels. J. Acoust. Soc. Am. 141:3689. doi: $10.1121 / 1.4988032$

Goldstein, T., Johnson, S. P., Phillips, A. V., Hanni, K. D., Fauguier, D. A., and Gulland, F. M. D. (1999). Human-related injuries observed in live stranded pinnipeds along the central California coast 1986-1998. Aquat. Mamm. $25,43-51$

Gorzelany, J. F. (2004). Evaluation of boater compliance with manatee speed zones along the Gulf coast of Florida. Coast. Manag. 32, 215-226. doi: 10.1080/0892075490448514

Graber, J. (2011). Land-based infrared imagery for marine mammal detection (Ph.D. thesis). University of Washington, Washington, DC, United States.

Graham, R. T., and Roberts, C. M. (2007). Assessing the size, growth rate and structure of a seasonal population of whale sharks (Rhincodon typus Smith 1828) using conventional tagging and photo identification. Fish. Res. 84, 71-80. doi: 10.1016/j.fishres.2006.11.026

Greig, A. B., Secchi, E. R., Zerbini, A. N., and Rosa, D. L. (2001). Stranding events of southern right whales, Eubalaena australis, in southern Brazil. J. Cetacean. Res. Manage. 2, 157-160.

Groch, K. R., Díaz-Delgado, J., Marcondes, M. C. C., Colosio, C., Santos-Neto, E. B., Carvalho, V. L., et al. (2018). Pathology and causes of death in stranded humpback whales (Megaptera novaeangliae) from Brazil. PLoS ONE 13:e0194872. doi: 10.1371/journal.pone.0194872

Gudger, E. W. (1938a). Four whale sharks rammed by steamers in the Red Sea region. Copeia 4, 170-173.

Gudger, E. W. (1938b). Whale sharks struck by fishing boats off the coast of lower California. California Fish Game 24, 420-421.

Guo, J. (2006). River dolphins down for the count, and perhaps out. Science 314:1860. doi: 10.1126/science.314.5807.1860

Guzman, H. M., Gomez, C. G., Guevara, C. A., and Kleivane, L. (2012). Potential vessel collisions with Southern Hemisphere humpback whales wintering off Pacific Panama. Mar. Mamm. Sci. 29, 629-642. doi: 10.1111/j.1748-7692.2012.00605.x

Hartman, D. S. (1979). Ecology and Behavior of the Manatee (Trichechus manatus) in Florida. Pittsburgh, PA: American Society of Mammalogists.
Hazel, J., and Gyuris, E. (2006). Vessel-related mortality of sea turtles in Queensland, Australia. Wildl. Res. 33, 149-154. doi: 10.1071/WR04097

Hazel, J., Lawler, I. R., Marsh, H., and Robson, S. (2007). Vessel speed increases collision risk for the green turtle Chelonia mydas. Endanger. Species Res. 3, 105-113. doi: 10.3354/esr003105

Hazevoet, C. J., Monteiro, V., López, P., Varo, N., Torda, G., Berrow, S., et al. (2010). Recent data on whales and dolphins (Mammalia: Cetacea) from the Cape Verde Islands, including records of four taxa new to the archipelago. Zoologia Caboverd. 1, 75-99.

Heppel, S. S., Crowder, L. B., and Menzel, T. R. (1999). "Life table analysis of longlived marine species with implications for conservation and management," in Life in the Slow Lane: Ecology and Conservation of Long-Lived Marine Animals, American Fisheries Society Symposium Volume 23, ed J. A. Musick (Bethesda, MD: American Fisheries Society), 137-148.

Hill, A. N., Karniski, C., Robbins, J., Pitchford, T., Todd, S., and AsmutisSilvia, R. (2017). Vessel collision injuries on live humpback whales, Megaptera novaeangliae, in the southern Gulf of Maine. Mar. Mamm. Sci. 33, 558-573. doi: $10.1111 / \mathrm{mms} .12386$

Hodgson, A. J. (2004). Dugong behaviour and responses to human influences (Ph.D. thesis). Townsville, QLD: School of Tropical Environment Studies and Geography, James Cook University.

Honma, Y., Ushiki, T., Takeda, M., Naito, E., Dewa, K., and Yamanouchi, H. (1999). Identification by histological and microsatellite analyses of a stranded beaked whale as that struck previously by a jetfoil operating in the Sea of Japan. Fish. Sci. 65, 547-552. doi: 10.2331/fishsci.65.547

Horton, T. W., Oline, A., Hauser, N., Khan, T. M., Laute, A., Stoller, A., et al. (2017). Thermal imaging and biometrical thermography of humpback whales. Front. Mar.Sci. 4:424. doi: 10.3389/fmars.2017. 00424

Ilangakoon, A. D. (2012). Exploring anthropogenic activities that threaten endangered blue whales (Balaenoptera musculus) off Sri Lanka. J. Mar. Anim. Ecol. 5, 3-7.

International Maritime Organization (1986). General Provisions of Ships' Routeing. Resolution A.572(14) Adopted in November 1986. London: International Maritime Organization.

International Maritime Organization (2003). New and Amended Traffic Separation Schemes. International Regulations for Preventing Collisions at Sea COLREG.2/Circ.53 adopted in December 2002. London: International Maritime Organization.

International Maritime Organization (2006). New and Amended Traffic Separation Schemes. International Regulations for Preventing Collisions at Sea COLREG.2/Circ.58 adopted in December 2006. London: International Maritime Organization.

International Maritime Organization (2007a). New and Amended Traffic Separation Schemes. International Regulations for Preventing Collisions at Sea COLREG.2/Circ.58/Corr.1. London: International Maritime Organization.

International Maritime Organization (2007b). Routeing Measures Other Than Traffic Separation Schemes. International Maritime Organization Safety of Navigation Circular SN.1/Circ.263 adopted in October 2007. London: International Maritime Organization.

International Maritime Organization (2008). Routeing Measures Other Than Traffic Separation Schemes. International Maritime Organization Safety of Navigation Circular SN.1/Circ.272 Adopted in November 2008. London: International Maritime Organization.

International Maritime Organization (2009). Guidance Document for Minimizing the Risk of Ship Collisions with Cetaceans. International Maritime Organization Marine Environment Protection Committee Circular MEPC.1/Circ.674 adopted in July 2009. London: International Maritime Organization.

International Maritime Organization (2012). New and Amended Traffic Separation Schemes. International Regulations for Preventing Collisions at Sea COLREG.2/Circ.64 adopted in November 2012. London: International Maritime Organization.

International Maritime Organization (2014). New Traffic Separation Schemes. International Regulations for Preventing Collisions at Sea COLREG.2/Circ.65 adopted in May 2014. London: International Maritime Organization.

International Maritime Organization (2016). Identification and Protection of Special Areas and PSSAs: Information on Recent Outcomes Regarding Minimizing Ship Strikes to Cetaceans. International Maritime Organization 
Marine Environment Protection Committee document MEPC 69/10/3. London: International Maritime Organization.

International Maritime Organization (2017). Routeing Measures Other Than Traffic Separation Schemes. International Maritime Organization Safety of Navigation circular SN.1/Circ.335 adopted in June 2017. London: International Maritime Organization.

International Union for the Conservation of Nature (2019). The International Union for the Conservation of Nature Red List of Threatened Species, International Union for the Conservation of Nature. Available online at: http:// www.iucnredlist.org (accessed June 2, 2019).

International Whaling Commission (2005). Annual Report of the International Whaling Commision 2005. Report of the $57^{\text {th }}$ Annual Meeting Held in Ulsan in 2005. Cambridge, UK: International Whaling Commission.

International Whaling Commission (2007). Ship Strikes Working Group First Progress Report to the Conservation Committee. Agenda item 4.2: IWC/58/CC2, discussed at the $58^{\text {th }}$ annual meeting of the International Whaling Commission. Cambridge, UK: International Whaling Commission.

International Whaling Commission (2011). Report of the Joint IWC-ACCOBAMS Workshop on Reducing Risk of Collisions between Vessels and Cetaceans. Agenda item 4.1: IWC/63/CC8, Discussed at the 63rd International Meeting Commission. Cambridge, UK: International Whaling Commission.

International Whaling Commission (2014). Report of the Joint IWC-SPAW Workshop to Address Collisions Between Marine Mammals and Ships With a Focus on the Wider Caribbean. Report IWC/65/CCrep01 discussed at the $14^{\text {th }}$ Meeting of the Western Gray Whale Advisory Panel. Cambridge, UK: International Whaling Commission.

International Whaling Commission (2019a). A Joint IWC-IUCN-ACCOBAMS Workshop to Evaluate How the Data Process Used to Identify Important Marine Mammal Areas (IMMAs) Can Assist the IWC to Identify Areas of High Risk for Ship Strike. Report of the International Whaling Commission Scientific Committee SC/68A/HIM/07 discussed at the annual Scientific Committee meeting held in Nairobi in 2019. Cambridge, UK: International Whaling Commission.

International Whaling Commission (2019b). Ship strike Database Data. Available online at: https://portal.iwc.int/shipstrike (accessed on August 14, 2019).

Irvine, A. B., and Campbell, H. W. (1978). Aerial census of the West Indian manatee, Trichechus manatus, in the southeastern United States. J. Mammal. 59, 613-617. doi: 10.2307/1380237

Izadi, S., Johnson, M., de Soto, N. A., and Constantine, R. (2018). Night-life of Bryde's whales: ecological implications of resting in baleen whale. Behav. Ecol. Sociobiol. 72:78. doi: 10.1007/s00265-018-2492-8

Jacobson, E. R. (1998). "Buoyancy problems in sea turtles: causes and diagnosis," in Proceedings of the Seventeenth Annual Sea Turtle Symposium, eds S. P. Epperl, and J. Braun (Miami, FL: National Marine Fisheries Service), 67.

Jefferson, T. A. (2000). Population biology of the Indo-Pacific hump-backed dolphin in Hong Kong waters. Wildl. Monogr. 144, 1-65.

Jefferson, T. A., Curry, B. E., and Konoshita, R. (2002). Mortality and morbidity of Hong Kong finless porpoises, with emphasis on the role of environmental contaminants. Raffl. Bull. Zool. 10, 161-171.

Jensen, A. S., and Silber, G. K. (2003). Large Whale Ship Strike Database. NOAA Technical Memorandum NMFS-OPR. Silver Spring, MD: US Department of Commerce.

Jepson, P. (2005). Cetacean Strandings Investigation and Co-ordination in the UK. Trends in Cetacean Strandings Around the UK Coastline and Cetacean and Marine Turtle Post-Mortem Investigations, 2000 to 2004 Inclusive. Report (Contract CRO 238) prepared for the Department for Environment, Food and Rural Affairs (Defra) for the period 1st January 2000-31st December 2004. London: Crown.

Jeri, J. C., Guzman, H., and Leslie, A. (2019). The Last Fluke of the Trip: Preventing Ship Strike Risk for Humpback Whales in Peru. Paper SC/68A/HIM/09 discussed at the Annual Scientific Committee meeting held in Nairobi in 2019. Cambridge, UK: International Whaling Commission.

Jett, J. S., and Thapa, B. (2010). Manatee zone compliance among boaters in Florida. Coast. Manag. 38, 165-185. doi: 10.1080/089207510036 68454

Johnston, D. W., and Woodley, T. H. (1998). A survey of acoustic harassment device (AHD) use in the Bay of Fundy, NB, Canada. Aquat. Mamm. $24,51-61$.
Joy, R., Tollit, D., Wood, J., MacGillivray, A., Li, Z., Trounce, K., et al. (2019). Potential benefits of vessel slowdowns on endangered southern resident killer whales. Front. Mar. Sci. 6:344. doi: 10.3389/fmars.2019.00344

Keen, E. M., Scales, K. L., Rone, B. K., Hazen, E. L., Falcone, E. A., and Schorr, G. S. (2019). Night and day: diel differences in ship strike risk for fin whales (Balaenoptera physalus) in the California current system. Front. Mar. Sci. 6:730. doi: 10.3389/fmars.2019.00730

Kelly, C., Glegg, G. A., and Speedie, C. D. (2004). Management of marine wildlife disturbance. Ocean Coast. Manag. 47, 1-19. doi: 10.1016/j.ocecoaman.2004.03.001

Kemper, C. M., Flaherty, A., Gibbs, S. E., Hill, M., Long, M., and Byard, R. W. (2005). Cetacean captures, strandings and mortalities in South Australia 18812000, with special reference to human interactions. Austr. Mammal. 27, 37-47. doi: 10.1071/AM05037

Kessel, S. T., Gruber, S. H., Gledhill, K. S., Bond, M. E., and Perkins, R. G. (2013). Aerial survey as a tool to estimate abundance and describe distribution of a Carcharhinid species, the lemon shark, Negaprion brevirostris. J. Mar. Biol. 2013:597383. doi: $10.1155 / 2013 / 597383$

Ketten, D. R. (2002). Marine mammal auditory systems: a summary of audiometric and anatomical data and implications for underwater acoustic impacts. Polarforschung 72, 79-92.

Knowlton, A., Gerrior, P., and McWeeny, W. (2007). Implementation of Merchant Mariner Education Modules Titled "Voyage Planning and Marine Environmental Protection Measures to Avoid Collisions With the North Atlantic right Whale" at US Maritime Academies. Final report (Order \#EM133F05SE5512) to the NMFS. Silver Spring, MA: National Marine Fisheries Service.

Knowlton, A. R., and Kraus, S. D. (2001). Mortality and serious injury of Northern right whales (Eubalaena glacialis) in the western North Atlantic Ocean. J. Cetac. Res. Manage. 2, 193-208.

Kozak, G. (2012). Side Scan Sonar Target Comparative Techniques for Port Security and MCM Q-Route Requirements. Salem, NH: L-3 Communications Klein Associates.

Kraus, S. D., Brown, M. W., Caswell, H., Clark, C. W., Fujiwara, M., Hamilton, P. D., et al. (2005). North Atlantic right whales in crisis. Science 309, 561-562. doi: $10.1126 /$ science. 1111200

Kreuder, C., Miller, M. A., Jessup, D. A., Lowenstine, L. J., Harris, M. D., Ames, J. A., et al. (2003). Patterns of mortality in southern sea otters (Enhydra lutris nereis) from 1998-2001. J. Wildl. Dis. 39, 495-509. doi: 10.7589/0090-3558-39.3.495

Lagerquist, B., Winsor, M., and Mate, B. (2013). Active Acoustic Deterrence of Migratory Whales. Final Technical Report (DE-EE0002660) for the US Department of Energy. Portland, OR; US: Pacific Energy Ventures.

Lagueux, K. M., Zani, M. A., Knowlton, A. R., and Kraus, S. D. (2011). Response by vessel operators to protection measures for right whales Eubalaena glacialis in the southeast US calving ground. Endanger. Species Res. 14, 69-77. doi: $10.3354 /$ esro0335

Lair, S., Martineau, D., and Measures, L. N. (2014). Causes of mortality in St. Lawrence estuary beluga (Delphinapterus leuca) from 1983-2012. Ottawa, ON: Fisheries and Ocean Canada.

Laist, D. W., Knowlton, A. R., Mead, J. G., Collet, A. S., and Podesta, M. (2001). Collisions between ships and whales. Mar. Mamm. Sci. 17, 35-75. doi: 10.1111/j.1748-7692.2001.tb00980.x

Laist, D. W., Knowlton, A. R., and Pendleton, D. (2014). Effectiveness of mandatory vessel speed limits for protecting North Atlantic right whales. Endanger. Species Res. 23, 133-147. doi: 10.3354/esr 00586

Laist, D. W., and Shaw, C. (2006). Preliminary evidence that boat speed restrictions reduce deaths of Florida manatees. Mar. Mamm. Sci. 22, 472-479. doi: $10.1111 / \mathrm{j} .1748-7692.2006 .00027 . \mathrm{x}$

Lammers, M. O., Pack, A. A., and Davis, L. (2003). Historical Evidence of Whale/Vessel Collisions in Hawaiian Waters (1975-present). Technical Report. Honolulu: Ocean Science Institute.

Leal, N., Leal, E., and Sanchez, G. (2015). Marine vessel recognition by acoustic signature. ARPN J. Eng. Appl. Sci. 10, 9633-9639.

Leaper, R. (2019). The role of slower vessel speeds in reducing greenhouse gas emissions, underwater noise and collision risk to whales. Front. Mar. Sci. 6:505. doi: $10.3389 /$ fmars.2019.00505 
Lenhardt, M. L. (2002). Marine Turtle Acoustic Repellent/Alerting Apparatus and Method. US Patent No 6,388,949 B1. Arlington, VA: Sound Technique Systems.

Lightsey, J. D., Rommel, S. A., Costidis, A. M., and Pitchford, T. D. (2006). Methods used during gross necropsy to determine watercraft-related mortality in the Florida manatee (Trichechus manatus latirostris). J. Zool. Wildl. Med. 37, 262-275. doi: 10.1638/04-095.1

Lockyer, C. H., and Morris, R. J. (1990). "Some observations on wound healing and persistence of scars in Tursiops truncates," in Individual Recognition of Cetaceans: Use Of Photo-Identification And Other Techniques To Estimate Population Parameters, eds P. S. Hammond, S. A. Mizroch, and G. P. Donovan (Cambridge, UK: International Whaling Commission), 113-118.

Lubofsky, E. (2019). Can Thermal Cameras Prevent Ship Strikes? Article on the Woods Hole Oceanographic Institution. Available online at: https://www. whoi.edu/news-insights/content/can-thermal-cameras-prevent-ship-strikes/ (accessed on September 10, 2019).

Luksenburg, J. A. (2014). Prevalence of external injuries in small cetaceans in Aruban waters, southern Caribbean. PLOS ONE 9:88988. doi: 10.1371/journal.pone.0088988

Lulham, A. (2006). Giant Sunfish Alarm Crews, the Daily Telegraph. Available online at: http://www.theaustralian.com.au/news/giant-sunfish-alarm-crews/ story-e6frg6n6-1111112730169 (accessed on May 31, 2019).

Maitland, R. N., Lawler, I. R., and Sheppard, J. K. (2006). Assessing the risk of boat strike on Dugongs Dugong dugong at Burrum Heads, Queensland, Australia. Pac. Conserv. Biol. 12, 321-326. doi: 10.1071/PC060321

Maritime New Zealand (2019). Annual NZ Notices to Mariners, Section 10: Shipping Routes Around the New Zealand coast. New Zealand nautical almanac 2019-20. Wellington: Maritime New Zealand.

Martin, J., Sabatier, Q., Gowan, T. A., Giraud, C., Gurarie, E., Calleson, C. S., et al. (2016). A quantitative framework for investigating risk of deadly collisions between marine wildlife and boats. Methods Ecol. Evol. 7, 42-50. doi: 10.1111/2041-210X.12447

Martinez, E., and Stockin, K. A. (2013). Blunt trauma observed in a common dolphin Delphinus sp. likely caused by a vessel collision in the Hauraki Gulf, New Zealand. Pac. Conserv. Biol. 19, 19-27. doi: 10.1071/PC130019

Martins, C. C. A., Andriolo, A., Engel, M. H., Kinas, P. G., and Saito, C. H. (2013). Identifying priority areas for humpback whale conservation at eastern Brazilian coast. Ocean Coast. Manag. 75, 63-71. doi: 10.1016/j.ocecoaman.2013.02.006

Mayol, P. (2012). REPCET Realtime Plotting of Cetaceans: Presentation of the System. La Celle: Souffleurs d'Ecume.

Mayol, P., Beaubrun, P., Capoulade, F., and Mugnier, P. (2008). Whale-Ship Collisions: Work and Outlook from a Team in the Pelagos Sanctuary, the Example of the REPCET Project. Agenda item 4: IWC/60/CC9rev, discussed at the 60th International Meeting Commission. Santiago: International Whaling Commission.

McAloose, D., Rago, M. V., Di Martino, M., Chirifie, A., Olson, S. H., Beltramino, L., et al. (2016). Post-mortem findings in southern right whales Eubalaena australis at Península Valdés, Argentina, 2003-2012. Dis. Aquat. Organ. 119, 17-36. doi: $10.3354 /$ dao02986

McFee, W. E., and Hopkins-Murphy, S. R. (2002). Bottlenose dolphin (Tursiops truncatus) strandings in South Carolina, 1992-1996. Fish. Bull. 100, 258-265.

McKenna, M. F., Calambokidis, J., Oleson, E. M., Laist, D. W., and Goldbogen, J. A. (2015). Simultaneous tracking of blue whales and large ships demonstrates limited behavioral responses for avoiding collision. Endanger. Species Res. 27, 219-232. doi: 10.3354/esr00666

McKenna, M. F., Katz, S. L., Condit, C., and Walbridge, S. (2012). Response of commercial ships to a voluntary speed reduction measure: are voluntary strategies adequate for mitigating ship-strike risk? Coast. Manag. 40, 634-650. doi: 10.1080/08920753.2012.727749

McWhinnie, L. H., Halliday, W. D., Insley, S. J., Hilliard, C., and Canessa, R. R. (2018). Vessel traffic in the Canadian Arctic: management solutions for minimizing impacts on whales in a changing northern region. Ocean Coast. Manag. 160, 1-17. doi: 10.1016/j.ocecoaman.2018.03.042

Meager, J. J. (2016). Marine Wildlife Stranding and Mortality Database Annual Report 2013-2015: Dugong. Conservation technical and data report. Brisbane, QLD: Department of Environment and Heritage Protection, Queensland Government.

Meager, J. J., and Limpus, C. J. (2012a). Marine Wildlife Stranding and Mortality Database Annual Report 2011: I Dugong. Conservation technical and data report 2011. Brisbane, QLD: Department of Environment and Heritage Protection.

Meager, J. J., and Limpus, C. J. (2012b). Marine Wildlife Stranding and Mortality Database Annual Report 2012: III Marine Turtles. Conservation technical and data report 2012. Brisbane, QLD: Department of Environment and Heritage Protection.

Monzón-Argüello, C., Cardona, L., Calabuig, P., Camacho, M., Crespo-Picazo, J. L., García-Párraga, D., et al. (2018). Supplemental feeding and other anthropogenic threats to green turtles (Chelonia mydas) in the Canary Islands. Sci. Total Environ. 621, 1000-1011. doi: 10.1016/j.scitotenv.2017.10.126

Moore, K. T., and Barco, S. G. (2013). Handbook for Recognizing, Evaluating, and Documenting Human Interaction in Stranded Cetaceans and Pinnipeds. Springfield, VA: US Department of Commerce.

Moore, M. J., Knowlton, A. R., Kraus, S. D., McLellan, W. A., and Bonde, R. K. (2004). Morphometry, gross morphology and available histopathology in North Atlantic right whale (Eubalaena glacialis) mortalities (1970-2002). J. Cetac. Res. Manag. 6, 199-214.

Moore, M. J., van der Hoop, J., Barco, S. G., Costidis, A. M., Gulland, F. M., Jepson, P. D., et al. (2013). Criteria and case definitions for serious injury and death of pinnipeds and cetaceans caused by anthropogenic trauma. Dis. Aquat. Organ. 103, 229-264. doi: 10.3354/dao02566

Morgan, M. A., and Patton, G. W. (1990). Human Dolphin Interactions on the West Coast of Florida. MML Technical Report \#191. Sarasota, FL: Mote Marine Laboratory.

Morimura, N., and Mori, Y. (2019). Social responses of travelling finless porpoises to boat traffic risk in Misumi West Port, Ariake Sound, Japan. PLoS ONE. 14:0208754. doi: 10.1371/journal.pone.0208754

Morton, A. B., and Symonds, H. K. (2002). Displacement of Orcinus orca (L.) by high amplitude sound in British Columbia, Canada. ICES J. Mar. Sci. 59, 71-80. doi: 10.1006/jmsc.2001.1136

Nanayakkara, R. P., and Herath, H. M. J. C. B. (2017). Report on 14 large whales that died due to ship strikes off the coast of Sri Lanka, 2010-1014. J. Mar. Biol. 2017:6235398. doi: 10.1155/2017/6235398

National Marine Fisheries Service (2005). Recovery Plan for the North Atlantic Right Whale (Eubalaena Glacialis): Revision. Silver Spring, MD: National Marine Fisheries Service.

Neilson, J. L., Gabriele, C. M., Jensen, A. S., Jackson, K., and Straley, J. M. (2012). Summary of reported whale-vessel collisions in Alaskan waters. J. Mar. Biol. 2012:106282. doi: 10.1155/2012/106282

Nero, R. W., Cook, M., Coleman, A. T., Solangi, M., and Hardy, R. (2013). Using an ocean model to predict likely drift tracks of sea turtle carcasses in the north central Gulf of Mexico. Endanger. Species Res. 21, 191-203. doi: $10.3354 /$ esro0516

Newshub (2010). Penguin Gets Prosthetic Beak, Newshub. Available online at: https://www.newshub.co.nz/environmentsci/penguin-gets- prosthetic-beak2010112214 (accessed on May 31, 2019).

Nichol, L. M., Wright, B. M., O'Hara, P., and Ford, J. K. B. (2017). Risk of lethal vessel strikes to humpback and fin whales off the west coast of Vancouver Island, Canada. Endanger. Species Res. 32, 373-390. doi: 10.3354/ esr00813

Nowacek, D. P., Johnson, M. P., and Tyack, P. L. (2004). North Atlantic right whales (Eubalaena glacialis) ignore ships but respond to alerting stimuli. Proc. R. Soc. B 271, 227-231. doi: 10.1098/rspb.2003.2570

Obusan, M. C. M., Rivera, W. L., Siringan, M. A. T., and Aragones, L. V. (2016). Stranding events in the Philippines provide evidence for impacts of human interactions on cetaceans. Ocean Coast. Manag. 134, 41-51. doi: 10.1016/j.ocecoaman.2016.09.021

Olesiuk, P. F., Nichol, L. M., Sowden, M. J., and Ford, J. K. B. (2002). Effect of the sound generated by an acoustic harassment device on the relative abundance and distribution of harbor porpoises (Phocoena phocoena) in retreat passage, British Columbia. Mar. Mamm. Sci. 18, 843-862. doi: 10.1111/j.1748-7692.2002.tb01077.x

Orós, J., Torrent, A., Calabuig, P., and Déniz, S. (2005). Diseases and causes of mortality among sea turtles stranded in the Canary Islands, Spain (1998-2001). Dis. Aquat. Organ. 63, 13-24. doi: 10.3354/dao063013

Owen, H., Gillespie, A., and Wilkie, I. (2012). Postmortem findings from dugong (Dugong dugong) submissions to the university of Queensland: 1997-2010. J. Wildl. Dis. 8, 962-970. doi: 10.7589/2011-03-080 
Panigada, S., Donovan, G. P., Druon, J. N., Lauriano, G., Pierantonio, N., Pirotta, E., et al. (2017). Satellite tagging of Mediterranean fin whales: working towards the identification of critical habitats and the focussing of mitigation measures. Sci. Rep. 7:3365. doi: 10.1038/s41598-017-03560-9

Panigada, S., Pesante, G., Zanardelli, M., Capoulade, F., Gannier, A., and Weinrich, M. T. (2006). Mediterranean fin whales at risk from fatal ship strikes. Mar. Pollut. Bull. 52, 1287-1298. doi: 10.1016/j.marpolbul.2006.03.014

Panigada, S., and Ritter, F. (2018). $6^{\text {th }}$ Progress Report on the IWC Ship Strike Data Coordination. Report SC/67B/HIM/11 discussed at the annual Scientific Committee meeting held in Slovenia in 2018. Cambridge, UK: International Whaling Commission.

Parks, S. E., Warren, J. D., Stamieszkin, K., Mayo, C. A., and Wiley, D. (2012). Dangerous dining: surface foraging of North Atlantic right whales increases risk of vessel collisions. Biol. Lett. 8, 57-60. doi: 10.1098/rsbl.2011.0578

Parsons, E. C. M., and Jefferson, T. A. (2000). Post-mortem investigations on stranded dolphins and porpoises from Hong Kong waters. J. Wildl. Dis. 36, 342-356. doi: 10.7589/0090-355836.2.342

Peel, D., Smith, J. N., and Childerhouse, S. (2018). Vessel strike of whales in Australia: the challenges of analysis of historical incident data. Front. Mar. Sci. 5:69. doi: 10.3389/fmars.2018.00069

Pirotta, E., New, L., and Marcoux, M. (2018). Modelling beluga habitat use and baseline exposure to shipping traffic to design effective protection against prospective industrialization in the Canadian Arctic. Aquat. Conserv. 2018, 1-10. doi: 10.1002/aqc.2892

Popper, A. N., and Hawkins, A. (2012). The Effects of Noise on Aquatic Life. New York, NY: Springer-Verlag New York.

Popper, A. N., and Hawkins, A. (2016). The Effects of Noise on Aquatic Life II. New York, NY: Springer-Verlag New York.

Porcasi, J. F., and Andrews, S. L. (2001). Evidence for a prehistoric Mola mola fishery on the southern California coast. J. Calif. Gt. Basin Anthropol. 23, 51-66. doi: $10.2307 / 27825752$

Ports of Auckland (2015). Hauraki Gulf Transit Protocol for Commercial Shipping (Auckland, New Zealand: Port of Auckland). Available online at: https://www. poal.co.nz/sustain/Documents/150112-Transit\%20Protocol.pdf (accessed on: September 01, 2019).

Preen, T. (2000). Dugongs, Boats, Dolphins and Turtles in the TownsvilleCardwell Region and Recommendations for a Boat Traffic Management plan for the Hinchinbrook Dugong Protection Area. Research publication No. 67. Townsville, QLD: Great Barrier Reef Marine Park Authority.

Priyadarshana, T., Randage, S. M., Alling, A., Calderan, S., Gordon, J., Leaper, R., and Porter, L. (2015). Distribution patterns of blue whale (Balaenoptera musculus) and shipping off southern Sri Lanka. Reg. Stud. Mar. Sci. 3, 181-188. doi: 10.1016/j.rsma.2015.08.002

Rahim, Z. (2019). Japanese High-Speed Ferry 'Hits Whale', Injuring Dozens of Passengers, Independent. Available online at: https://www.independent.co.uk/ news/world/asia/japan-ferry-whale-crash-injury-sado-minke-humpbacka8815521.html (accessed on September 6, 2019).

Ramírez-Macías, D., Meekan, M., de la Parra-Venegas, R., Remolina-Suárez, F., Trigo-Mendoza, M., and Vázquez-Juárez, R. (2012). Patterns in composition, abundance and scarring of whale sharks Rhincodon typus near Holbox Island, Mexico. J. Fish Biol. 80, 1401-1416. doi: 10.1111/j.1095-8649.2012.03258.x

Record, N. R., Runge, J. A., Pendleton, D. E., Balch, W. M., Davies, K. T. A., Pershing, A. J., et al. (2019). Rapid climate-driven circulation changes threaten conservation of endangered North Atlantic right whales. Oceanography 32, 162-169. doi: 10.5670/oceanog.2019.201

Redfern, J. V., McKenna, M. F., Moore, T. J., Calambokidis, J., Deangelis, M. L., Becker, E. A., et al. (2013). Assessing the risks of ships striking large whales in marine spatial planning. Conserv. Biol. 27, 292-302. doi: 10.1111/cobi/12029

Redfern, J. V., Moore, T. J., Becker, E. A., Calambokidis, J., Hastings, S. P., Irvine, L. M., et al. (2019). Evaluating stakeholder-derived strategies to reduce the risk of ships striking whales. Diver. Distr. 25, 1575-1585. doi: 10.1111/ ddi. 12958

Ritter, F. (2012). Collisions of sailing vessels with cetaceans worldwide: first insights into a seemingly growing problem. J. Cetac. Res. Manag. 12, 119-127.

Ritter, F., de Soto, N. A., and Martín, V. (2019). Towards Ship Strike Mitigation In The Canary Islands. Report SC/68A/HIM/15. Discussed at the Annual Scientific
Committee meeting held in Nairobi in 2019. Cambridge, UK: International Whaling Commission.

Rockwood, C. R., Calambokidis, J., and Jahncke, J. (2017). High mortality of blue, humpback and fin whales from modelling of vessel collisions on the US West coast suggests population impacts and insufficient protection. PLoS ONE. 12:e0183052. doi: 10.1371/journal.pone.0183052

Rommel, S. A., Costidis, A. M., Pitchford, T. D., Lightsey, J. D., Snyder, R. H., and Haubold, E. M. (2007). Forensic methods for characterizing watercraft from watercraft-induced wounds on the Florida manatee (Trichechus manatus latirostris). Mar. Mamm. Sci. 23, 110-132. doi: 10.1111/j.1748-7692.2006.00095.x

Rowat, D., Meekan, M. G., Engelhardt, U., Pardigon, B., and Vely, M. (2007). Aggregations of juvenile whale sharks (Rhincodon typus) in the Gulf of Tadjoura, Djibouti. Environ. Biol. Fishes 80, 465-472. doi: 10.1007/s10641-006-9148-7

Rowntree, V. J., Payne, R. S., and Schell, D. M. (2001). Changing patterns of habitat use by southern right whales (Eubalaena australis) on their nursery ground at Península Valdés, Argentina, and in their long-range movements. J. Cetac. Res. Manag. 2:1330143.

Rugh, D. J., Muto, M. M., Moore, S. E., and DeMaster, D. P. (1999). Status Review of the Eastern North Pacific Stock of Gray Whales. NOAA Technical Memorandum NMFS-AFSC-103. Springfield, VA: US Department of Commerce.

Runge, M. C., Sanders-Reed, C. A., Langtimm, C. A., Hostetler, J. A., Deutsch, C. J., Ward-Geiger, L. I., et al. (2017). Status and Threats Analysis for the Florida Manatee (Trichechus manatus latirostris), 2016. Scientific Investigations Report 2017-5030 prepared in cooperation with the Florida Fish and Wildlife Conservation Commission. Reston, VA: US Geological Survey.

Santos, M. C. O., Campolim, M. B., Parada, I. L. S., Dunker, P., and da Silva, E. (2010). The triumph on the commons: working towards the conservation of Guiana dolphins (Sotalia guianensis) in the Cananéia estuary Brazil. Lat. Am. J. Aquat. Res. 8, 187-190. doi: 10.5597/lajam00169

Scordino, J., Carretta, J., Cottrell, P., Greenman, J., Savage, K., Scordino, J., et al. (2017). "Ship strikes and entanglements of gray Whales in the North Pacific Ocean, 1924-2015," Paper SC/67A/HIM/06 Presented at the Annual Scientific Committee Meeting Held in Slovenia in 2017. (Cambridge, UK: International Whaling Commission).

Segniagbeto, G. H., Okangny, D., Mondedji, A. D., Delagnon, A., Amori, G., Dendi, D., et al. (2017). Sea turtle bycatch analysis revealed that site influenced mortality more than net types along the coast of Togo. Life Environ. $67,227-234$.

Sharp, S. M., McLellan, W. A., Rotstein, D. S., Costidis, A. M., Barco, S. G., Durham, K., et al. (2019). Gross and histopathological diagnoses from North Atlantic right whale Eubalaena glacialis mortalities between 2003 and 2018. Dis. Aquat. Organ. 135, 1-31. doi: 10.3354/dao03376

Sierra, E., Fernández, A., de los Monteros, A. E., Arbelo, M., Díaz-Delgado, J., Andrada, M., et al. (2014). Histopathological muscle findings may be essential for a definitive diagnosis of suspected sharp trauma associated with ship strikes in stranded cetaceans. PLoS ONE 9:e88780. doi: 10.1371/journal.pone.0088780

Silber, G. K., Adams, J. D., Asaro, M. J., Cole, T. V. N., Moore, K. S., and Ward-Geiger, L. I. (2015). The right whale mandatory ship reporting system: a retrospective. PeerJ 3:e866. doi: 10.7717/peerj.866

Silber, G. K., Adams, J. D., and Bettridge, S. (2012a). Vessel operator response to a voluntary measure for reducing collisions with whales. Endanger. Species Res. 17, 245-254. doi: 10.3354/esr00434

Silber, G. K., Adams, J. D., and Fonnesbeck, C. J. (2014). Compliance with vessel speed restrictions to protect North Atlantic right whales. PeerJ 2:e399. doi: $10.7717 /$ peerj.399

Silber, G. K., Slutsky, J., and Bettridge, S. (2010). Hydrodynamics of a ship/whale collision. J. Exp.Mar. Biol. Ecol. 391, 10-19. doi: 10.1016/j.jembe.2010.05.013

Silber, G. K., Vanderlaan, A. S. M., Arceredillo, A. T., Johnson, L., Taggart, C. T., Brown, M. W., et al. (2012b). The role of the International Maritime Organization in reducing vessel threat to whales: process, options, action and effectiveness. Mar. Policy 36, 1221-1233. doi: 10.1016/j.marpol.2012.03.008

Souffleurs d'Ecume (2012). REPCET; Real Time Plotting of Cetaceans. Souffleurs d'Ecume. Available online at: http://repcet.com (accessed on May 31, 2019).

Speed, C. W., Meekan, M. G., Rowat, D., Pierce, S. J., Marshall, A. D., and Bradshaw, C. J. A. (2008). Scarring patterns and relative mortality 
rates of Indian Ocean whale sharks. J. Fish Biol. 72, 1488-1503. doi: 10.1111/j.1095-8649.2008.01810.x

Speedie, C. D., and Johnson, L. A. (2008). The Basking Shark (Cetorhinus Maximus) in West Cornwall. Natural England Research Report NERR018. Sheffield: Natural England.

Speedie, C. D., Johnson, L. A., and Witt, M. J. (2009). Basking Shark Hotspots on the West Coast of Scotland: Key Sites, Threats and Implications for Conservation of the Species. Commissioned report no. 339. Inverness: Scottish Natural Heritage.

Stone, G. S., and Yoshinaga, A. (2000). Hector's dolphin Cephalorhynchus hectori calf mortalities may indicate new risks from boat traffic and habituation. Pac. Conserv. Biol. 6, 162-172. doi: 10.1071/PC000162

Stroud, R. K., and Roffe, T. J. (1979). Causes of death in marine mammals stranded along the Oregon coast. J. Wildl. Dis. 15, 91-97. doi: 10.7589/0090-355815.1.91

Swails, K. S. (2005). Patterns of seal strandings and human interactions in Cape Cod, Massachuettes (Ph.D. thesis) Nicholas School of the Environment and Earth Sciences of Duke University, Durham, NC, United States.

Thomas, P. O., Reeves, R. R., and Brownell, Jr. R. L. (2016). Status of the world's baleen whales. Mar. Mamm. Sci. 32, 682-734. doi: 10.1111/mms.12281

Thorpe, A. (2010). Measurements Techniques, Sensors and Platforms. London: Academic Press, Elsevier.

Tomás, J., Gozalbes, P., Raga, J. A., and Godley, B. J. (2008). Bycatch of loggerhead sea turtles: insights from 14 years of stranding data. Endanger. Species Res. 5, 161-169. doi: 10.3354/esr00116

Towner, A., Smale, M. J., and Jewell, O. (2012). "Boat-strike wound healing in Carcharodon carcharias." in Global Perspectives on the Biology and the Life History of the White Shark, ed M. L. Domeier (Boca Raton, FL: CRC Press), 77-83.

United Nations Conference on Trade and Development (2018). 50 Years of Review of Maritime Transport, 1968-2018: Reflecting in the Past, Exploring the Future. Geneva: United Nations Conference on Trade and Development.

van der Hoop, J. M., Moore, M. J., Barco, S. G., Cole, T. V. N., Daoust, P. Y., Henry, A. G., et al. (2013). Assessment of management to mitigate anthropogenic effects on large whales. Conserv. Biol. 27, 121-133. doi: 10.1111/j.1523-1739.2012.01934.x

van der Hoop, J. M., Vanderlaan, A. S. M., Cole, T. V. N., Henry, A. G., Hall, L., Mase-Guthrie, B., et al. (2015). Vessel strikes to large whales before and after the 2008 ship strike rules. Conserv. Lett. 8, 24-32. doi: 10.1111/ conl.12105

van der Hoop, J. M., Vanderlaan, A. S. M., and Taggart, C. T. (2012). Absolute probability estimates of lethal vessel strikes to North Atlantic right whales in Roseway Basin, Scotian Shelf. Ecol. Applic. 22, 2021-2033. doi: 10.1890/11-1841.1

van der Meer, J. (2006). An introduction to Dynamic Energy Budget (DEB) models with special emphasis on parameter estimation. J. Sea Res. 56, 85-102. doi: 10.1016/j.seares.2006.03.001

van Parijs, S. M., Clark, C. W., Sousa-Lima, R. S., Parks, S. E., Rankin, S., Risch, D., et al. (2009). Management and research applications of real-time and archival passive acoustic sensors over varying temporal and spatial scales. Mar. Ecol. Prog. Series 395, 21-36. doi: 10.3354/meps08123

van Waerebeek, K., Baker, A. N., Félix, F., Gedamke, J., Iniguez, M., Sanino, G. P., et al. (2007). Vessel collisions with small cetaceans worldwide and with large whales in the Southern Hemisphere, an initial assessment. Lat. Am. J. Aquat. Mamm. 6, 43-69. doi: 10.5597/lajam00109

van Waerebeek, K., and Leaper, R. (2008). Second Report of the IWC Vessel Strike Data Standardisation Working Group. Report presented at the $60^{\text {th }}$ annual meeting of the IWC in Santiago, Chile, in 2008 Cambridge, UK: International Whaling Commission.

Vanderlaan, A. S. M., and Taggart, C. T. (2007). Vessel collisions with whales: the probability of lethal injury based on vessel speed. Mar. Mamm. Sci. 23, 144-156. doi: 10.1111/j.1748-7692.2006.00098.x

Vanderlaan, A. S. M., and Taggart, C. T. (2009). Efficacy of a voluntary area to be avoided to reduce risk of lethal vessel strikes to endangered whales. Conserv. Biol. 23, 1467-1474. doi: 10.1111/j.1523-1739.2009. 01329.x
Vanderlaan, A. S. M., Taggart, C. T., Serdynska, A. R., Kenney, R. D., and Brown, M. W. (2008). Reducing the risk of lethal encounters: vessels and right whales in the Bay of Fundy and on the Scotian Shelf. Endanger. Species Res. 4, 283-297. doi: 10.3354/esr00083

Visser, I. N. (1999). Propeller scars on and known home range of two orca (Orcinus orca) in New Zealand waters. N Z J. Mar. Freshwater Res. 33, 635-642. doi: 10.1080/00288330.1999.9516906

Visser, I. N., and Fertl, D. (2000). Stranding, resighting, and boat strike of a killer whale (Orcinus orca) off New Zealand. Aquat. Mamm. 26, 232-240.

Wang, C., Lyons, S. B., Corbett, J. J., and Firestone, J. (2007). Using ship Speed and Mass do Describe Potential Collision Severity with Whales: an Application of the Ship Traffic, Energy and Environment Model (STEEM) [Report by the University of Delaware]. Available online at: https://tethys.pnnl.gov/publications/usingship-speed-and-mass-describe-potential-collision-severity-whales (accessed on September 15, 2019).

Ward-Geiger, L. I., Silber, G. K., Baumstark, R. D., and Pulfer, T. L. (2005). Characterization of ship traffic in right whale critical habitat. Coast. Manag. 33, 263-278. doi: 10.1080/08920750590951965

Webster, T. A., van Parijs, S. M., Rayment, W. J., and Dawson, S. M. (2019). Temporal variation in the vocal behaviour of southern right whales in the Auckland Islands, New Zealand. R Soc. Open Sci. 6:181487. doi: $10.1098 /$ rsos.181487

Weinrich, M., Panigada, S., and Guinet, C. (2005). Report of the Joint ACCOBAMS/Pelagos Workshop on Large Whale Ship Strikes in the Mediterranean Sea. Monaco:ACCOBAMS.

Weinrich, M., Pekarcik, C., and Tackaberry, J. (2010). The effectiveness of dedicated observers in reducing risks of marine mammal collisions with ferries: a test of the technique. Mar. Mamm. Sci. 26, 460-470. doi: 10.1111/j.1748-7692.2009.00343.x

Weir, C. R., and Pierce, G. J. (2012). A review of the human activities impacting cetaceans in the eastern tropical Atlantic. Mamm. Rev. 43, 258-274. doi: 10.1111/j.1365-2907.2012.0022.x

Wells, R. S., Allen, J. B., Hofmann, S., Bassos-Hull, K., Fauquier, D. A., Barros, N. B., et al. (2008). Consequences of injuries on survival and reproduction of common bottlenose dolphins (Tursiops truncatus) along the west coast of Florida. Mar. Mamm. Sci. 24, 774-794. doi: 10.1111/j.1748-7692.2008. 00212.x

Wells, R. S., and Scott, M. D. (1997). Seasonal incidence of boat strikes on bottlenose dolphins near Sarasota, Florida. Mar. Mamm. Sci. 13, 475-480. doi: 10.1111/j.1748-7692.1997.tb00654.x

Wickens, P. A., and Sims, P. F. (1994). Trawling operations and South African (Cape) fur seals, Arctocephalus pusillus pusillus. Mar. Fish. Rev. $56,1-12$.

Wiley, D. N., Asmutis, R. A., Pitchford, T. D., and Gannon, D. P. (1995). Stranding and mortality of humpback whales, Megaptera novaeangliae, in the mid-Atlantic and Southeast United States, 1985-1992. Fish. Bull. 93, 196-205.

Wiley, D. N., Mayo, C. A., Maloney, E. M., and Moore, M. J. (2016). Vessel strike mitigation lessons from direct observations involving two collisions between noncommercial vessels North Atlantic right whales (Eubalaena glacialis). Mar. Mamm. Sci. 32, 1501-1509. doi: 10.1111/mms.12326

Williams, R., Gero, S., Bejder, L., Calambokidis, J., Kraus, S. D., Lusseau, D., et al. (2011). Underestimating the damage: Interpreting cetacean carcass recoveries in the context of the deepwater horizon/BP incident. Conserv. Lett. 4, 228-233. doi: 10.1111/j.1755-263X.2011.00168.x

Williams, R., and O'Hara, P. (2010). Modelling ship strike risk to fin, humpback and killer whales in British Columbia, Canada. J. Cetac. Res. Manag. $11,1-8$.

Wilson, S. C., Trukhanova, I., Dmitrieva, L., Dolgova, E., Crawford, I., Baimukanov, M., et al. (2017). Assessment of impacts and potential mitigation for icebreaking vessels transiting pupping areas of an ice-breeding seal. Biol. Conserv. 214, 213-222. doi: 10.1016/j.biocon.2017.05.028

Witzell, W. N. (2007). Kemp's Ridley (Lepidochelys kempi) shell damage. Mar. Turtle Newslett. 115, 16-17.

Wong, B. B. M., and Candolin, U. (2015). Behavioral response to changing environments. Behav. Ecol. 26, 665-673. doi: 10.1093/beheco/aru183 
Work, P. A., Sapp, A. L., Scott, D. W., and Dodd, M. G. (2010). Influence of small vessel operation and propulsion system on loggerhead sea turtle injuries. J. Exp. Mar. Biol. Ecol. 393, 168-175. doi: 10.1016/j.jembe.2010.07.019

Work, T. M., Balazs, G. H., Summers, T. M., Hapdei, J. R., and Tagarino, A. P. (2015). Causes of mortality in green turtles from Hawaii and the insular Pacific exclusive of fibropapillomatosis. Dis. Aquat. Organ. 115, 103-110. doi: 10.3354/dao02890

Yonehara, Y., Kagami, L., Yamada, H., Kato, H., Terada, M., and Okada, S. (2012). Feasibility on infrared detection of cetaceans for avoiding collisions with hydrofoil. Int. J. Mar. Navig. Saf. Sea Transport. 6, 149-154. doi: $10.1201 / \mathrm{b} 11346-41$
Conflict of Interest: The authors declare that the research was conducted in the absence of any commercial or financial relationships that could be construed as a potential conflict of interest.

Copyright $\odot 2020$ Schoeman, Patterson-Abrolat and Plön. This is an open-access article distributed under the terms of the Creative Commons Attribution License (CC $B Y)$. The use, distribution or reproduction in other forums is permitted, provided the original author(s) and the copyright owner(s) are credited and that the original publication in this journal is cited, in accordance with accepted academic practice. No use, distribution or reproduction is permitted which does not comply with these terms. 